Article

\title{
Biodegradable Nanoparticles Made of Amino-Acid-Based Ester Polymers: Preparation, Characterization, and In Vitro Biocompatibility Study
}

\author{
Temur Kantaria ${ }^{1}$, Tengiz Kantaria ${ }^{1}$, Sophio Kobauri ${ }^{1}$, Mariam Ksovreli ${ }^{2}$, Tinatin Kachlishvili ${ }^{2}$, \\ Nina Kulikova ${ }^{2}$, David Tugushi ${ }^{1}$ and Ramaz Katsarava ${ }^{1, *}$ \\ 1 Institute of Chemistry and Molecular Engineering, Agricultural University of Georgia, Tbilisi 0159, Georgia; \\ temurkant@gmail.com (Tem.K.); tengizkantaria@gmail.com (Ten.K.); s.kobauri@agruni.edu.ge (S.K.); \\ d.tughushi@agruni.edu.ge (D.T.) \\ 2 Cellular Immunology Laboratory, Agricultural University of Georgia, Tbilisi 0159, Georgia; \\ m.ksovreli@agruni.edu.ge (M.K.); t.kachlishvili@agruni.edu.ge (T.K.); n.kulikova@agruni.edu.ge (N.K.) \\ * Correspondence: r.katsarava@agruni.edu.ge; Tel.: +995-599-15-92-02
}

Academic Editor: Jordi Puiggalí

Received: 20 November 2016; Accepted: 8 December 2016; Published: 17 December 2016

\begin{abstract}
A systematic study of fabricating nanoparticles (NPs) by cost-effective polymer deposition/solvent displacement (nanoprecipitation) method has been carried out. Five amino acid based biodegradable (AABB) ester polymers (four neutral and one cationic), four organic solvents miscible with water, and eight surfactants were tested for the fabrication of the goal NPs. Depending on the nature of the AABB polymers, organic solvents and surfactants, as well as on the fabrication conditions, the size (Mean Particle Diameter) of the NPs could be tuned within $42 \div 398 \mathrm{~nm}$, the zeta-potential within $12.5 \div+28 \mathrm{mV}$. The stability (resuspendability) of the NPs upon storage (at room temperature and refrigerated) was tested as well. In Vitro biocompatibility study of the NPs was performed with four different stable cell lines: A549, HeLa (human); RAW264.7, Hepa 1-6 (murine). Comparing the NPs parameters, their stability upon storage, and the data of biological examinations the best were found: As the AABB polymer, a poly(ester amide) composed of L-leucine, 1,6-hexanediol and sebacic acid-8L6, as a solvent (organic phase-DMSO), and as a surfactant, Tween 20.
\end{abstract}

Keywords: amino acids; biodegradable polymers; nanoprecipitation; nanoparticles; systematic study; nanoparticles stability; in vitro cell compatibility

\section{Introduction}

Nanoparticles (NPs) based drug delivery systems have considerable potential for treatment of many human diseases. The important technological advantages of nanoparticles used as drug carriers (nanocontainers) are high stability, high carrier capacity, feasibility of encapsulation both-hydrophilic or hydrophobic substances, and feasibility of variable routes of administration, including oral application and inhalation. NPs can also be designed to allow controlled (sustained) drug release from the matrix. These properties of NPs enable improvement of drug bioavailability and reduction of the dosing frequency, as well as to fulfill targeted and controlled administration, and may resolve the problem of nonadherence to prescribed therapy, which is one of the major obstacles in the control of epidemics.

A variety of nanoparticulate-based drug delivery systems have been developed: liposomes, dendimers, $\beta$-cyclodextrin, various emulsions, and nanospheres [1-4]. Liposomes and emulsions of liposomes are less popular because of their short shelf life, limited drug capacity, aggressive conditions used for their preparation and problems in sterilization [5]. More promising for drug delivery are nanospheres [4] referred to as nanoparticles (NPs) below. 
Various degradable and non-degradable polymers of both natural and synthetic origin such as albumin [6,7], acrylic polymers [8-10], polystyrene [11], polycyanoacrylates [12], poly(epsilon-caprolactone) $[13,14]$, poly(lactic acid) $[15,16]$, to name a few, were used in nanodrug formulations. One can say without exaggeration that preference should be given to NPs made of biodegradable polymers which will be cleared from the body after the fulfillment of their function. The most promising are synthetic biodegradable polymers with low immunogenicity such as poly(caprolactone), poly(lactic acid) and poly(lactic-co-glycolic acid), etc. These polyester class of biomaterials, however, produce acidic products (glycolic and lactic acids with $\mathrm{pK}_{\mathrm{a}} 3.83$ and 3.86, accordingly) during degradation that are considered to be toxic and induce undesired phenotype modulation in cells [17]. Besides, polyesters showed lower affinity to living tissues (due to the lack of hydrophilic CO-NH bonds in the backbones) [18] that can decrease the bioavailability of the NPs prepared from this type of polymers. Hence, better candidates for medical and pharmacological applications are biodegradable polymers containing peptide-like $\mathrm{CO}-\mathrm{NH}$ links in the backbones that increase polymer-tissue affinity and, therefore, particles designed from these polymers are expected to have improved bioavailability. At the same time polyesters show reasonable rate of biodegradation as compared with other hetero-chain polymers such as polyamides, polyurethanes and polyureas-The polymers which contain desirable $\mathrm{CO}-\mathrm{NH}$ links but biodegrade much slowly. Therefore, more promising look hybrids of polyesters with these hetero-chain polymers-Poly(ester amide)s (PEAs), poly(ester urethane)s (PEURs), and poly(ester urea)s (PEUs), which combine useful properties of "parent polymers"-Polyesters and CO-NH links containing polymers such as polyamides, polyurethanes, and polyureas. Especially attractive are the polymers composed of physiological building blocks-Naturally occurring $\alpha$-amino acids and other non-toxic building blocks such as fatty diols and dicarboxylic acids, amino-acid-based biodegradable (AABB) polymers [17,19-27]. The AABB polymers showed better biocompatibility compared to polyesters [17,23-25] along with wider range of material properties and look more promising for sophisticated biomedical applications [17,19-30], including the construction of the biodegradable particulates promising as drug delivery containers.

The AABB PEAs were successfully used for constructing nanobiocomposites containing bacteriophages along with other medications which showed a high wound healing potential [31,32]. Various leucine-based PEA were used as drug eluting vascular stent coatings [27,33-35], for obtaining micronized particles-Microfibriles [36] and microspheres [37]—For intraocular delivery of a lipophilic drug, dexamethasone, and the particles showed excellent biocompatibility and provided sustained drug delivery. The phenylalanine-based PEAs were used for preparing Paclitaxel loaded microspheres with a high encapsulation efficiency (close to $100 \%$ ) having the potential for the injection administration of highly hydrophobic anticancer drugs [38]. The AABB PEUs showed outstanding mechanical characteristics along with a high biocompatibility and in vivo biodegradability and are promising in regenerative medicine for load bearing orthopedic applications [39,40]. At the same time less is known about the capability of the AABB polymers to form nanosized particle (NPs) of desired size, zeta-potential and stability.

It is important to emphasize here that the AABB polymers are especially attractive as biodegradable biomaterials for the applications with tissues highly sensitive to acidic media because after ultimate biodegradation they release neutral products such as $\alpha$-amino acid, fatty diol and $\mathrm{CO}_{2}$ or dicarboxylic acids of lower acidity and in lower quantities (per unit mass of the polymer) compared to glycolic and lactic acids [30]. Besides, some AABB polymers revealed self-buffering property $[39,40]$. Hence, after the biodegradation of the AABB polymers very low or no local acidic environment causing inflammation is built up. Since the biodegradable micro and nanoscaled devices are frequently used as containers for a drug delivery to the tissues highly sensitive to acidic media, the AABB polymers look especially promising for constructing such kind of drug containers.

The present paper is a systematic study of fabricating NPs from the AABB polymers using nanoprecipitation (polymer deposition/solvent displacement) method from a solution in water-miscible organic solvent to water in the presence of surfactants as the NPs stabilizers. Four AABB polymers 
(two PEAs and two PEUs), four water-miscible organic solvents and eight surfactants were included in the research plan. The research plan covered also the in vitro cell compatibility study of the selected samples of NPs with four established cell lines.

\section{Materials and Methods}

Eight surfactants-Tween 20 Sorbitanmonolaurate (MW 1228), Tween 40 Sorbitanmonopalmitate (MW 1277), Tween 80 Sorbitanmonooleate (MW 1310), Kolliphor P188 PPO-PEO-PPO triblock copolymer (MW, 7680-9510), Brij 010 Polyoxyethylene(10)oleyl ether (MW 709), Poly(vinyl alcohol)s (PVAs) such as Mowiol 4-88, MW 31,000 of 86.7\%-88.7\% hydrolyzed and Mowiol 8-88, MW 67,000 of $86.7 \%-88.7 \%$ hydrolyzed, purchased from Sigma-Aldrich (St. Louis, MO, USA), and Ttriton X100 Poly(ethylene glycol)p-(1,1,3,3-tetramethyl-butyl)-phenyl ether (MW 647) purchased from Ferak Berlin $\mathrm{GmbH}$ (Berlin, Germany), were used as received. Organic solvents-1,3-Dimethyl-2-imidazolidinone (DMI), N,N-Dimethylformamide (DMF), acetone and 1,1,1,3,3,3-hexafluoroisopropanol (HFIP) were purchased from Sigma-Aldrich, and Dimethylsulfoxide (DMSO) from Carl Roth (Karlsruhe, Germany). All the solvents were used as received. The dialysis bag (MWCO $25 \mathrm{kDa}$ ) was purchased from Spectrum Laboratories, Inc., Rancho Dominguez, CA, USA. The AABB polymers, selected for the proposed study (Figure 1), were originally synthesized as reported previously [23,30]-The PEUs 1F6 and 1L6 and the PEA 8L6 via the Interfacial Polycondensation (IP), and the PEA 4F4 via the Solution Active Polycondensation (SAP). The biodegradable cationic AABB polymer-arginine (R) based PEA 8R6 (Figure 2) was synthesized as reported previously using SAP [41].
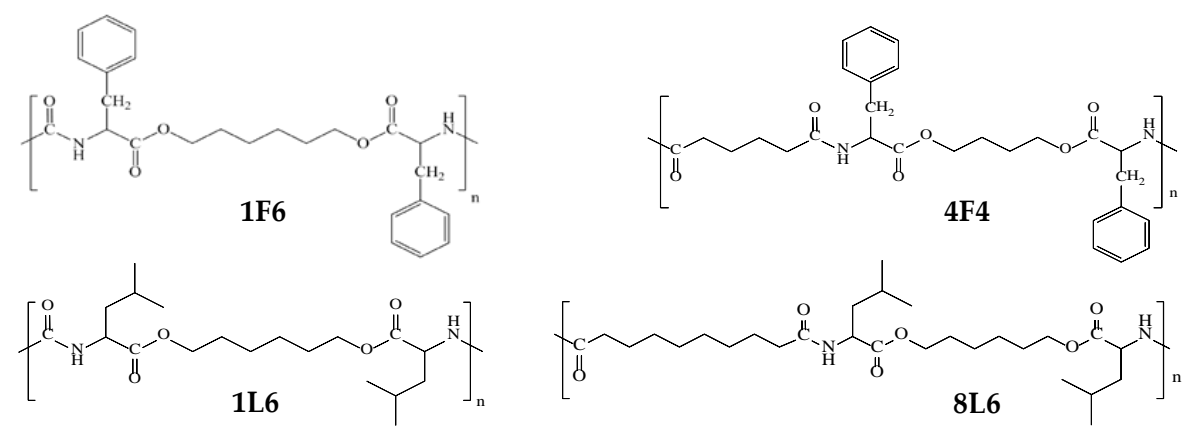

Figure 1. The chemical structures of the neutral AABB polymers used for fabricating the NPs.<smiles>CC(C)(C)NC(CCNC(N)=NC(=O)O)C(=O)OC(C)(C)COC(=O)C(CCCNC(N)NCO)NC(=O)C(C)(C)C(=O)C(C)(C)C</smiles>

$\mathrm{Tos} \mathrm{OH}=p$-Toluenesulfonic acid

Figure 2. The chemical structure of the cationic AABB polymer $\mathbf{8 R 6}$ used for fabricating the positively charged NPs.

The number-average $\left(M_{n}\right)$, and weight-average $\left(M_{w}\right)$ molecular weights (MW), and molecular weight distribution (MWD) of the polymers were determined using the GPC. The MWs of the neutral polymers 1F6, 1L6, 4F4 and 8L6 were determined on a machine of Waters Associates, Inc., Milford, MA, USA, equipped with Styragel columns in DMF: HR4, HR3, HR0.5 all $7.8 \mathrm{~mm} \times 300 \mathrm{~mm}$ ), a high-pressure liquid chromatography pump (Waters 1525 Binary HPLC) and a Waters refractive index detector 2414 and UV-detector (Waters 2487 dual absorbance detector, $\lambda=240 \mathrm{~nm}$, Waters Associates, Inc., Milford, MA, USA). The polymers was dissolved in and eluted with DMF containing $\mathrm{LiBr}(0.1 \mathrm{M})$. The injected volume was $100 \mu \mathrm{L}$, the sample concentration was $5.0 \mathrm{mg} / \mathrm{mL}$, and the flow rate was $1.0 \mathrm{~mL} / \mathrm{min}$. The columns were calibrated with PMMA standards. The MW of the cationic polymer $\mathbf{8 R 6}$ was determined on a Shimadzu GPC machine, model LC-8A equipped with an 
Empower computer program (Waters), a PL HFIP gel column (Polymer Lab, Theale, Berkshire, UK) and a refractive index detector (Shimadzu RID-10A, Shimadzu Scientific Instruments, Columbia, MD, USA). The polymer was dissolved in and eluted with HFIP containing $\mathrm{CF}_{3} \mathrm{COONa}(0.05 \mathrm{M}$, to suppress polyelectrolyte effects). The injected volume was $100 \mu \mathrm{L}$, the sample concentration was $2.0 \mathrm{mg} / \mathrm{mL}$, and the flow rate was $0.5 \mathrm{~mL} / \mathrm{min}$. The columns were calibrated with PMMA standards.

Four different established cell lines (two murine, two human) were used: HeLa-Human epithelial cells from cervical cancer (ATCC CCL-2 ${ }^{\mathrm{TM}}$, Manassas, VA, USA), A549-Human alveolar epithelial type II cells derived from lung carcinoma (ATCC CCL-185 ${ }^{\mathrm{TM}}$, Manassas, VA, USA), Hepa1-6-Mouse hepatoma-derived cells (ATCC CRL-1830 ${ }^{\mathrm{TM}}$, Manassas, VA, USA), and RAW264.7-Mouse leukemic monocyte macrophage cell line (ATCC TIB-71 ${ }^{\mathrm{TM}}$, Manassas, VA, USA). All four cell lines (HeLa, A549, Hepa 1-6, and RAW264.7) are adherent and have be maintained in Dulbecco's Modified Eagle's Medium (DMEM) culture medium supplemented with $10 \%$ fetal bovine serum (FBS), $2 \mathrm{mM}$ L-glutamine, 100 units of penicillin $/ \mathrm{mL}$, and $100 \mu \mathrm{g}$ of streptomycin $/ \mathrm{mL}$ at $37^{\circ} \mathrm{C}$ in a $5 \% \mathrm{CO}_{2}$ incubator. Cells were harvested with trypsin $(0.25 \%) / \mathrm{Na}_{2}$ EDTA (Ethylenediaminetetraacetate disodium salt) solution.

\subsection{Preparation of the NPs (General Procedure)}

The NPs were prepared according to the polymer deposition/solvent displacement (nanoprecipitation) method reported in [42]. All the experiments of the NPs fabrication were performed at room temperature (r.t.). In a typical procedure a predetermined amount (varied) of AABB polymer was dissolved in $1.0 \mathrm{~mL}$ of an organic solvent miscible with water (DMI, DMSO, DMF, or acetone). This organic phase was then added dropwise (the dropping rate was varied) to a predetermined volume (varied) of the aqueous phase containing a predetermined concentration (varied) of a surfactant (varied), at a predetermined stirring rate (varied) using a magnetic stirrer. The influence of the various factors such as the nature of the AABB polymers, organic solvents, and surfactants, as well as various parameters like a polymer concentration in the organic phase, surfactant concentration in the aqueous phase, the organic/water phase ratio, the rate of adding (dropping) of the organic phase to the water phase, and the stirring rate of the water phase on the NPs fabrication was studied.

The NPs were also fabricated via the modified nanoprecipitation method. According to this method a surfactant $(50 \mathrm{mg}$ ) was dissolved in $1.0 \mathrm{~mL}$ of the organic solvent (DMI) along with an AABB polymer $(6.0 \mathrm{mg})$ and the organic phase was added dropwise $(12 \mathrm{drops} / \mathrm{min})$ to $10.0 \mathrm{~mL}$ of pure water at the stirring rate $700 \mathrm{rpm}$.

In all cases, after adding the organic phase, the aqueous phase became turbid, which indicated the formation of NPs. The suspensions of the NPs, obtained after the complete addition of the organic phase, were stirred for $2-3 \mathrm{~min}$ and stored either at r.t. or refrigerated with the purpose to study the NPs stability under different storage conditions. For biological studies the suspensions of NPs obtained under the optimal conditions ( $1.0 \mathrm{~mL}$ of DMSO solution containing $6.0 \mathrm{mg}$ of a polymer, $10.0 \mathrm{~mL}$ of the water phase containing $5.0 \mathrm{mg}$ of a surfactant (the organic/water phases $(\mathrm{O} / \mathrm{W})$ ratio 1:10, dropping rate 12 drops/min, and stirring rate $700 \mathrm{rpm}$ ) were dialyzed against distilled water for $72 \mathrm{~h}$ to remove the organic solvent and residual surfactant using the dialysis bag with MWCO $25 \mathrm{kDa}$. After dialysis the volume of suspension was reduced to $10.0 \mathrm{~mL}$ by evaporating water on a rotary evaporator under reduced pressure. For TEM measurements the volume was reduced to $1.0 \mathrm{~mL}$ (i.e., to the concentration of the NPs, $6.0 \mathrm{mg} / \mathrm{mL}$ ).

The aggregation of the NPs (if any) was assessed visually by the appearance of small (macro size) pieces of the polymer.

\subsection{NPs Size, Zeta-Potential and Morphology}

The NPs were characterized by size (Mean Particle Diameter, MPD) and size distribution (Polydispersity Index, PDI), and zeta-potential (ZP), which were assessed by dynamic light scattering (DLS) using a particle size analyzer (Zetasizer Nano ZS, Malvern Instruments, Malvern, UK) at $25^{\circ} \mathrm{C}$. The MPD and PDI are presented as an average of three measurements \pm standard deviation (SD). 
The PDI $<0.04$ corresponds to a narrow distribution, $0.04 \leq$ PDI $\leq 0.16-$ To a mean distribution, and PDI $>0.16$ - To a wide distribution.

The morphological examination of the NPs was performed on a transmission electron microscope, TEM, model BS-500, TESLA, Brno, Czechoslovakia, using negative staining of the samples with uranyl acetate solution (1\%). Briefly, a drop of concentrated suspension of NPs $(6 \mathrm{mg} / \mathrm{mL})$ was placed on a TEM grid surface with a filter paper. A drop of uranyl acetate solution was added to the surface of the formvar-coated grid. After $1 \mathrm{~min}$ incubation, excess fluid was removed and the grid surface was air-dried at room temperature before being loaded into the microscope.

\subsection{Cytotoxicity (MTT) Assay}

For the cytotoxicity testing of HeLa, A549, Hepa 1-6, and RAW264.7, cells were harvested with trypsin, resuspended in media containing $10 \% \mathrm{FBS}$ at a density $0.5 \times 10^{6} \mathrm{cell} / \mathrm{mL}$, and plated on 96 -well cell culture plates. After $24-28 \mathrm{~h}$ of growth, after $80 \%$ confluence has been reached, the cell culture medium was changed to serum-free and nanoparticles were added at a concentration of $5.0 \mu \mathrm{g} / \mathrm{mL}$. After $24 \mathrm{~h}$, the cytotoxicity of NPs was assessed by 3-(4,5-dimethylthiazol-2-yl)-2,5-diphenyltetrazolium bromide (MTT) assay [43] based on the ability of a mitochondrial dehydrogenase enzyme in viable cells to cleave the tetrazolium rings of the pale yellow MTT and form a dark blue formazan crystal. The number of surviving cells is directly proportional to the level of the formazan product created, which can then be quantified by reading absorbance at a wavelength of $570 \mathrm{~nm}$ with a multiwell scanning spectrophotometer (ELx800 Absorbance Reader, Biotek, Inc., Winooski, VT, USA). Briefly, after cells were incubated with a nanoparticle-containing media for $24 \mathrm{~h}, 10 \mu \mathrm{L}$ MTT solution was added to the medium and the mixtures were incubated for $4 \mathrm{~h}$ at $37^{\circ} \mathrm{C}$, followed by addition of $100 \mu \mathrm{L}$ DMSO to dissolve the purple crystals with gentle pipetting. The absorbance at a wavelength of $570 \mathrm{~nm}$ was read on the ELx800 Absorbance Reader (Biotek). In control samples cells were cultured with medium only. Cell viability was calculated using the equation:

$$
\text { Cell viability }(\%)=\frac{([O D] \text { test }-[\text { OD }] \text { blank })}{([O D] \text { control }-[\text { OD }\} \text { blank })} \times 100 \%
$$

where [OD]test, [OD]control, and [OD]blank represented the absorbance values of the wells with cells and NPs, cells without NPs, and without NPs and cells, respectively. For each experiment the absorbance was the average value measured from 12 wells in parallel. Four independent experiments have been performed in case of each cell line used.

\section{Results}

\subsection{Selection of the Polymers}

The AABB polymers are a relatively new family of biodegradable biomaterials that are obtained by the interaction of basic bis-nucleophilic monomers, amino-acid-based diamine-diesters [23,30], with various bis-electrophiles using either IP (when using various dichlorides as bis-electrophiles) or SAP (when using various activated diesters as bis-electrophiles) $[22,23,30]$. Three main classes of AABB polymers-PEAs, PEURs, and PEUs-Were synthesized on the basis of diamine-diester monomers. For a systematic study of the NPs' fabrication process from the AABB polymers with the purpose of obtaining NPs of desired size, zeta-potential, and stability, two classes of AABB polymers-PEUs and PEAs - Were selected for the following reasons: The PEUs 1F6 and 1L6 and the PEA 8L6 are obtained using readily available purchasable and cheap bis-electrophilic monomers, triphosgene and sebacoyl chloride; the activated di-p-nitrophenyl ester of adipic acid used for synthesizing the PEA 4F4 was also obtained via the available adipoyl chloride. Among other reasons, apart from availability and cheapness, the selection of the PEUs and PEAs was stipulated by the glass transition temperatures $\left(T_{g}\right)$ of the polymers and a low pliability within the temperature range $20-40{ }^{\circ} \mathrm{C}$ (the temperature range within which the NPs are prepared and can be applied as drug carriers) of the polymers in 
either dry or wet state, which is important for preventing the NPs' aggregation. The third class of AABB polymers, PEURs, are synthesized using diol-bis-chloroformates [20], which are not purchasable monomers and should be custom-made. In addition, the AABB PEURs show low $T_{g}$ and are highly pliable, especially in wet state, which increases the chances of their aggregation under the conditions of the nanoprecipitation applied for fabricating the NPs.

As was emphasized above, after the biodegradation of the AABB polymers very little or no local acidity causing inflammation is built up [39,40]. Therefore, these polymers are especially promising for constructing biodegradable micro and nanoscaled devices used as containers for drug delivery to tissues that are highly sensitive to acidic media.

The neutral (having no charge) AABB polymers composed of hydrophobic $\alpha$-amino acids L-phenylalanine $(\mathbf{F})$ and L-leucine $(\mathbf{L})$, selected for a systematic study of the NPs fabrication using nanoprecipitation, were: Two PEUs, 1 F6 and 1L6, and two PEAs, 4F4 and 8L6. The structures of the selected AABB polymers are depicted in Figure 1; their MW characteristics are given in Table 1.

Table 1. MW characteristics of the AABB polymers used for fabricating the NPs.

\begin{tabular}{ccccc}
\hline Polymer & Class of the Polymers & $\boldsymbol{M}_{\boldsymbol{w}}$ & $\boldsymbol{M}_{\boldsymbol{n}}$ & $\boldsymbol{M}_{\boldsymbol{w}} / \boldsymbol{M}_{\boldsymbol{n}}$ \\
\hline 1F6 & PEU & 35,400 & 20,500 & 1.73 \\
1L6 & PEU & 90,400 & 54,100 & 1.67 \\
4F4 & PEA & 66,400 & 47,400 & 1.43 \\
8L6 & PEA & 46,500 & 23,400 & 1.98 \\
8R6 & PEA & 17,500 & 7,200 & 2.43 \\
\hline
\end{tabular}

One L-arginine (R)-based cationic AABB polymer, PEA 8R6 was also used in the present study for imparting the positive charge to the NPs via blending with the neutral polymers above. The $\mathbf{8 R} \mathbf{6}$ is rather hydrophobic and dissolves in water upon heating to $60-70{ }^{\circ} \mathrm{C}$ and precipitates when cooled to r.t. so it will not easily be washed out from the NPs in the water phase. The structure of the PEA $\mathbf{8 R 6}$ is depicted in Figure 2; its molecular weight characteristics are given in Table 1.

\subsection{Selection of the Organic Solvent}

The nature of an organic solvent is an important factor when fabricating NPs via nanoprecipitation. The organic solvent should dissolve the polymer as well as be miscible with water (an inorganic phase used for precipitating the NPs). Four hydrophilic solvents were tested on the polymers' solubility (Table 2). All the polymers were soluble in highly polar organic solvents such as DMI, DMSO, and DMF, and two of them (leucine-based polymers $1 \mathbf{L 6}$ and 8L6) were soluble in acetone as well. These four solvents were used as the organic phases for fabricating the NPs.

Table 2. Solubility of the PEAs and PEUs in organic solvents.

\begin{tabular}{ccccc}
\hline \multirow{2}{*}{ Polymer } & \multicolumn{4}{c}{ Solubility of $\mathbf{1 0} \mathbf{~ m g}$ of Polymer in $\mathbf{1 ~ m L ~ o f ~ t h e ~ S o l v e n t ~}$} \\
\cline { 2 - 5 } & DMI & DMSO & DMF & Acetone \\
\hline 1F6 & $+\mathrm{t}$ & $+\mathrm{t}$ & $+\mathrm{t}$ & - \\
1L6 & + & + & + & + \\
4F4 & + & + & + & - \\
8L6 & + & + & + & + \\
\hline \multirow{2}{*}{+ + soluble at r.t., } & - insoluble at r.t., + t soluble on heating up to $50{ }^{\circ} \mathrm{C}$.
\end{tabular}

Acetone as a volatile solvent is convenient to be removed from the nanosuspensions by evaporating under reduced pressure [42], whereas DMI, DMSO, and DMF could be removed by dialysis only.

\subsection{Fabrication of the NPS}

The influence of various factors on the fabrication of the NPs via nanoprecipitation was studied. The NPs were prepared according to the general procedure described in Section 2 above (see Materials and Methods). 
3.3.1. The Influence of a Polymer Concentration in the Organic Phase in the Presence of Various Surfactants in the Water Phase

In these experiments two neutral AABB polymers $1 F 6$ and $4 \mathrm{~F} 4$ and all eight surfactants were used. The parameters (invariable and variable) of the NPs fabrication process are given in the table below:

\begin{tabular}{|c|c|}
\hline \multicolumn{2}{|c|}{ Parameters of the Process } \\
\hline Invariable & Variable \\
\hline $\begin{array}{l}\text { - } \\
\text { - } \\
\text { - } \\
\text { - } \mathrm{O} / \mathrm{W} \text { ratio- }-1: 10 \\
\text { - } \quad \text { organic phase dropping rate }-12 \mathrm{drops} / \mathrm{min} \\
\text { stirring rate of the water phase }-700 \mathrm{rpm}\end{array}$ & $\begin{array}{l}\text { - } \quad \text { polymers (two)-1L6 and 4F4 } \\
\text { - } \quad \text { concentrations of a polymer in the organic } \\
\text { phase-0.6, 3.0 and } 6.0 \mathrm{mg} / \mathrm{mL} \\
\text { - } \quad \text { surfactants (eight) - Tween 20, Tween 40, } \\
\text { Tween 80, Triton X-100, Kolliphor P188, } \\
\text { Brij 010, Mowiol 4-88, and Mowiol 8-88 }\end{array}$ \\
\hline
\end{tabular}

The conditions of the NPs' fabrication were as follows: The solvent: DMI; polymer concentration in the organic phase: $0.6,3.0$, or $6.0 \mathrm{mg} / \mathrm{mL}$; surfactant concentration in the water phase: $5 \mathrm{mg} / \mathrm{mL}$; the $\mathrm{O} / \mathrm{W}$ ratio: 1:10; the organic phase dropping rate: $12 \mathrm{drops} / \mathrm{min}$; and the stirring rate of the water phase: $700 \mathrm{rpm}$.

The results obtained for the selected AABB polymers 1F6 and 4F4 using all eight surfactants in terms of the mean diameters of the NPs are given schematically in Figures 3 and 4.

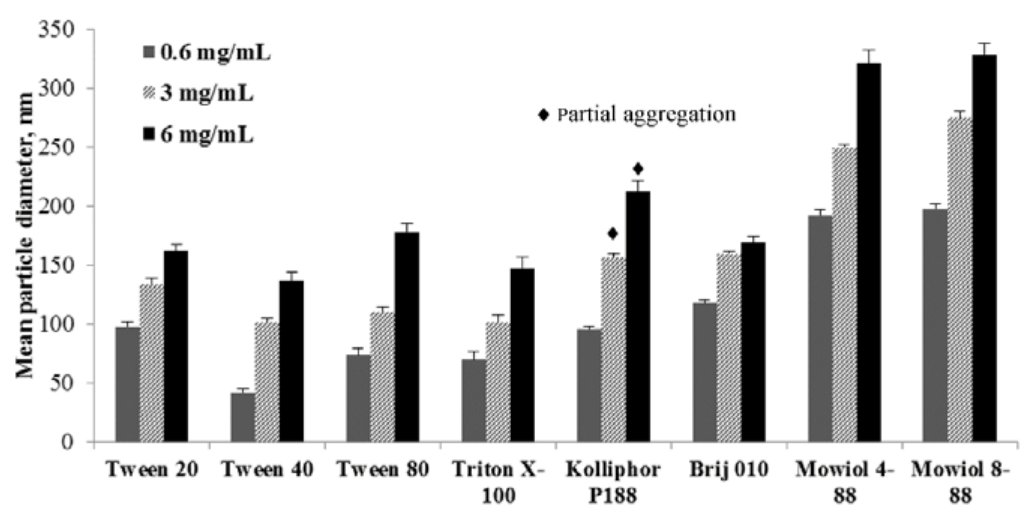

Figure 3. The influence of the polymer concentration in the organic phase on the formation of the 1F6 NPs in the presence of various surfactants in the water phase.

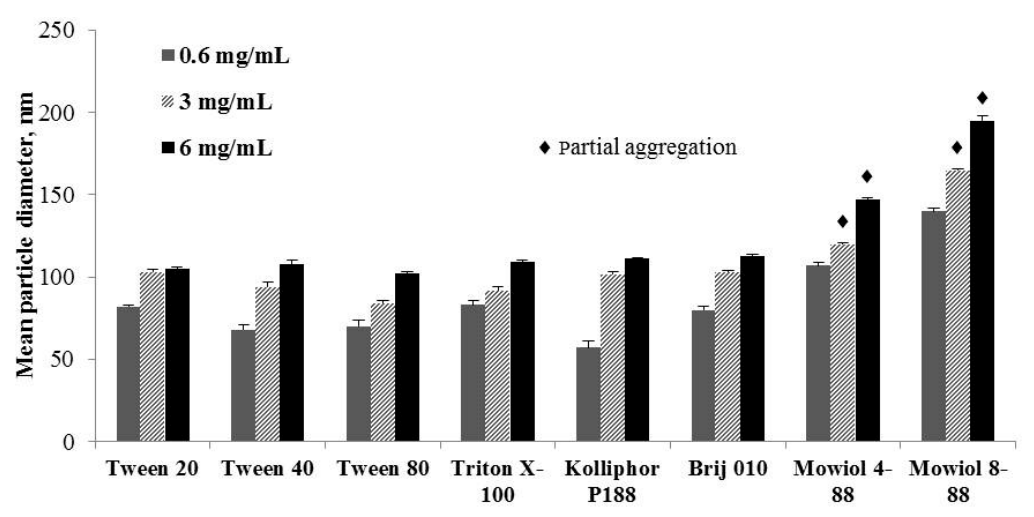

Figure 4. The influence of the polymer concentration in the organic phase on the formation of the 4F4 NPs in the presence of various surfactants in the water phase. 
When the polymers were precipitated in pure water (free of surfactants) full aggregation of the NPs was observed at all the concentrations used (Table 3).

Table 3. Nonoprecipitation of the AABB polymers 1F6 and 4F4 without surfactant.

\begin{tabular}{ccc}
\hline \multirow{2}{*}{$\mathbf{C}_{\mathbf{p o l}}(\mathbf{m g} / \mathbf{m L})$} & \multicolumn{2}{c}{ Polymer } \\
\cline { 2 - 3 } & 1F6 & 4F4 \\
\hline 0.6 & Full Aggregation & Full Aggregation \\
3.0 & Full Aggregation & Full Aggregation \\
6.0 & Full Aggregation & Full Aggregation \\
\hline
\end{tabular}

\subsubsection{The Influence of a Polymer's Nature}

All the neutral AABB polymers selected for the present study-1F6, 1L6, 4F4, and 8L6, and five of eight surfactants were involved in these experiments. The parameters (invariable and variable) of the NPs' fabrication process are given in the table below:

\begin{tabular}{|c|c|}
\hline \multicolumn{2}{|c|}{ Parameters of the Process } \\
\hline Invariable & Variable \\
\hline $\begin{array}{ll}\text { - } & \text { solvent-DMI } \\
\text { - } & \text { polymers' concentrations in the organic phase }-6.0 \mathrm{mg} / \mathrm{mL} \\
\text { - } & \text { concentration of a surfactant in water phase }-5 \mathrm{mg} / \mathrm{mL}) \\
\text { - } & \mathrm{O} / \mathrm{W} \text { ratio-1:10 } \\
\text { - } & \text { organic phase dropping rate }-12 \mathrm{drops} / \mathrm{min} \\
\text { - } & \text { stirring rate of the water phase }-700 \mathrm{rpm}\end{array}$ & $\begin{array}{l}\text { - } \quad \text { polymers (four)-1F6, 1L6, 4F4, and 8L6 } \\
\text { - } \quad \text { surfactants (five)-Tween 20, Triton X-100, } \\
\text { Brij 010, Mowiol 4-88, and Mowiol 8-88 }\end{array}$ \\
\hline
\end{tabular}

The conditions of the NPs' fabrication were as follows: the solvent: DMI; polymer concentration in the organic phase: $6.0 \mathrm{mg} / \mathrm{mL}$; surfactant concentration in the water phase: $5.0 \mathrm{mg} / \mathrm{mL} ; \mathrm{O} / \mathrm{W}$ ratio: 1:10, the organic phase dropping rate: $12 \mathrm{drops} / \mathrm{min}$; and the stirring rate of the water phase: $700 \mathrm{rpm}$. The results obtained for all the AABB polymers using five surfactants in terms of the MPD and PDI of the NPs are listed in Table 4.

Table 4. The influence of the AABB polymers on the fabrication of the NPs.

\begin{tabular}{|c|c|c|c|c|c|}
\hline \multirow{3}{*}{ Polymer } & \multicolumn{5}{|c|}{ Surfactant } \\
\hline & Tween 20 & Triton X-100 & Brij 010 & Mowiol 4-88 & Mowiol 8-88 \\
\hline & \multicolumn{5}{|c|}{$\mathrm{MPD}(\mathrm{nm}) \pm \mathrm{SD} \quad[\mathrm{PDI}] \pm \mathrm{SD}$} \\
\hline $1 \mathrm{~F} 6$ & $\begin{array}{c}\mathbf{1 4 3} \pm \mathbf{6} \\
{[0.123 \pm 0.019]}\end{array}$ & $\begin{array}{c}148 \pm \mathbf{6} \\
{[0.116 \pm 0.004]}\end{array}$ & $\begin{array}{c}\mathbf{1 6 0} \pm \mathbf{1 0} \\
{[0.268 \pm 0.009]}\end{array}$ & $\begin{array}{c}321 \pm \mathbf{4} \\
{[0.053 \pm 0.015]}\end{array}$ & $\begin{array}{c}328 \pm \mathbf{2} \\
{[0.075 \pm 0.019]}\end{array}$ \\
\hline $1 \mathrm{L6}$ & $\begin{array}{c}132 \pm \mathbf{7} \\
{[0.152 \pm 0.032]}\end{array}$ & $\begin{array}{c}140 \pm \mathbf{8} \\
{[0.172 \pm 0.091]}\end{array}$ & $\begin{array}{c}\mathbf{1 3 6} \pm \mathbf{1} \\
{[0.145 \pm 0.098]}\end{array}$ & $\begin{array}{c}\mathbf{2 1 8} \pm \mathbf{6} \\
{[0.102 \pm 0.056]}\end{array}$ & $\begin{array}{c}\mathbf{2 6 0} \pm \mathbf{1 0} \\
{[0.192 \pm 0.086]}\end{array}$ \\
\hline $4 \mathrm{~F} 4$ & $\begin{array}{c}158 \pm \mathbf{7} \\
{[0.111 \pm 0.006]}\end{array}$ & $\begin{array}{c}139 \pm 7 \\
{[0.121 \pm 0.009]}\end{array}$ & $\begin{array}{c}\mathbf{1 6 3} \pm \mathbf{1 0} \\
{[0.299 \pm 0.013]}\end{array}$ & $\begin{array}{c}\mathbf{1 7 3} \pm \mathbf{9} \\
{[0.117 \pm 0.009]}\end{array}$ & $\begin{array}{c}240 \pm \mathbf{1 0} \\
{[0.224 \pm 0.008]}\end{array}$ \\
\hline $8 \mathrm{~L} 6$ & $\begin{array}{c}\mathbf{1 5 9} \pm \mathbf{3} \\
{[0.131 \pm 0.003]}\end{array}$ & $\begin{array}{c}\mathbf{1 5 4} \pm \mathbf{9} \\
{[0.090 \pm 0.003]}\end{array}$ & $\begin{array}{c}166 \pm \mathbf{5} \\
{[0.088 \pm 0.001]}\end{array}$ & $\begin{array}{c}144 \pm \mathbf{3} \\
{[0.076 \pm 0.006]}\end{array}$ & $\begin{array}{c}\mathbf{1 8 1} \pm \mathbf{6} \\
{[0.095 \pm 0.003]}\end{array}$ \\
\hline
\end{tabular}

\subsubsection{The Influence of a Surfactant's Concentration in the Water Phase}

In these experiments two neutral AABB polymers $1 \mathrm{~F} 6$ and 4F4, and four of eight surfactants were used. The parameters (invariable and variable) of the NPs fabrication process are given in table below: 


\begin{tabular}{|c|c|}
\hline \multicolumn{2}{|c|}{ Parameters of the Process } \\
\hline Invariable & Variable \\
\hline $\begin{array}{l}\text { - } \text { solvent-DMI } \\
\text { - } \text { concentration of the polymer in } \mathrm{DMI}-6.0 \mathrm{mg} / \mathrm{mL} \\
\text { - } \mathrm{O} / \mathrm{W} \text { ratio-1:10 } \\
\text { - } \quad \text { organic phase dropping rate-12 drops } / \mathrm{min} \\
\text { - } \quad \text { stirring rate of the water phase }-700 \mathrm{rpm}\end{array}$ & $\begin{array}{l}\text { - } \quad \text { polymers (two)-1F6 and 4F4 } \\
\text { - } \quad \text { surfactants (four)-Tween 20, Tween 80, } \\
\text { Triton X-100, Brij } 010 \\
\text { - } \quad \text { surfactant's concentration in the water } \\
\text { phase-2.0, 5.0, } 10.0 \text { and } 20.0 \mathrm{mg} / \mathrm{mL}\end{array}$ \\
\hline
\end{tabular}

The conditions of the NPs fabrication were as follows: the solvent: DMI; polymer concentration in the organic phase: $6.0 \mathrm{mg} / \mathrm{mL}$; surfactant concentration in the water phase: $2.0,5.0,10.0$ or $20.0 \mathrm{mg} / \mathrm{mL}$, accordingly, the $\mathrm{O} / \mathrm{W}$ ratio: 1:10; the organic phase dropping rate: 12 drops $/ \mathrm{min}$; and the stirring rate of the water phase: $700 \mathrm{rpm}$. The results obtained for the selected AABB polymers 1F6 and 4F4 using four surfactants in terms of the MPD and PDI of the NPs are given in Figure 5.
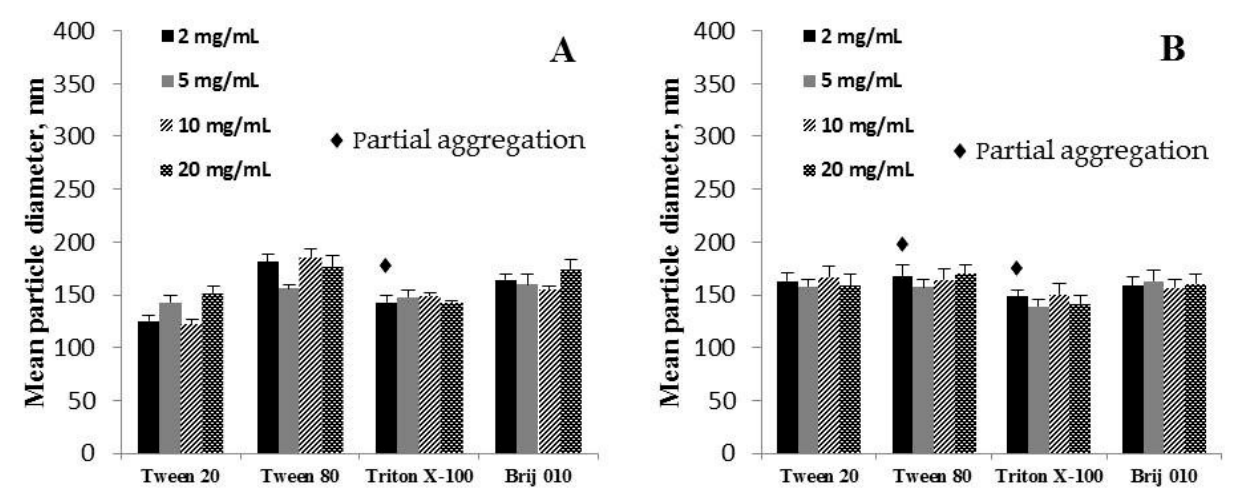

Figure 5. The influence of the surfactant concentration in the water phase on the formation of the 1F6 (A) and 4F4 (B) NPs.

\subsubsection{The Influence of an Organic Solvent}

All the neutral AABB polymers selected for the present study-1F6, 1L6, 4F4, and 8L6, five of eight surfactants, and four organic solvents-Were involved in these experiments. All the AABB polymers were soluble in the selected polar organic solvents such as DMI, DMF, and DMSO, and 8L6 and 1L6 were also soluble in acetone (for the solubility of the polymers see Table 2). The parameters (invariable and variable) of the NPs fabrication process are given in the table below:

\begin{tabular}{|c|c|}
\hline \multicolumn{2}{|c|}{ Parameters of the Process } \\
\hline Invariable & Variable \\
\hline $\begin{array}{l}\text { - } \text { concentration of the polymer in organic } \\
\text { phase- } 6.0 \mathrm{mg} / \mathrm{mL} \\
\text { - } \text { concentration of surfactant in the water } \\
\text { phase }-5.0 \mathrm{mg} / \mathrm{mL} \\
\text { - } \mathrm{O} / \mathrm{W} \text { ratio- }-1: 10 \\
\text { - } \quad \text { stirganic phase dropping rate of the water phase- }-700 \mathrm{rpm} \text {. }\end{array}$ & $\begin{array}{ll}\text { - } & \text { solvents (four)-DMI, DMF, DMSO, and acetone } \\
\text { - } & \text { polymers (four)-1F6, 1L6, 4F4 and 8L6 } \\
\text { - } & \text { surfactants (five)-Tween 20, Tween 80, Brij 010, } \\
\text { Kolliphor P-288, Mowiol 4-88. }\end{array}$ \\
\hline
\end{tabular}

The conditions of the NPs fabrication were as follows: Polymer concentration in an organic solvent: $6.0 \mathrm{mg} / \mathrm{mL}$; surfactant concentration in the water phase: $5.0 \mathrm{mg} / \mathrm{mL}$; the $\mathrm{O} / \mathrm{W}$ ratio: 1:10; the organic phase dropping rate: $12 \mathrm{drops} / \mathrm{min}$, and the stirring rate of the water phase: $700 \mathrm{rpm}$. The results obtained for all the AABB polymers using five surfactants and four organic solvents in terms of the MPD and PDI are listed in Tables 5-8. 
Table 5. The influence of the organic solvent on the formation of the 1F6 NPs in the presence of five surfactants.

\begin{tabular}{|c|c|c|c|c|c|}
\hline \multirow{3}{*}{ Organic Solvent } & \multicolumn{5}{|c|}{ Surfactant } \\
\hline & Tween 20 & Tween 80 & Kolliphor P188 & Brij 010 & Mowiol 4-88 \\
\hline & \multicolumn{5}{|c|}{$\operatorname{MPD}(\mathrm{nm}) \pm \mathrm{SD} \quad[\mathrm{PDI}] \pm \mathrm{SD}$} \\
\hline DMI & $\begin{array}{c}\mathbf{1 4 3} \pm \mathbf{6} \\
{[0.123 \pm 0.019]}\end{array}$ & $\begin{array}{c}\mathbf{1 5 6} \pm \mathbf{4} \\
{[0.218 \pm 0.063]}\end{array}$ & $\begin{array}{c}\mathbf{1 9 1} \pm \mathbf{6} \\
{[0.112 \pm 0.018]}\end{array}$ & $\begin{array}{c}\mathbf{1 6 0} \pm \mathbf{1 0} \\
{[0.268 \pm 0.009]}\end{array}$ & $\begin{array}{c}\mathbf{3 2 1} \pm \mathbf{4} \\
{[0.053 \pm 0.015]}\end{array}$ \\
\hline DMF & $\begin{array}{c}\mathbf{3 3 8} \pm \mathbf{9} \\
{[0.136 \pm 0.012]}\end{array}$ & $\begin{array}{c}311 \pm \mathbf{1 2} \\
{[0.147 \pm 0.019]}\end{array}$ & $\begin{array}{c}\mathbf{3 0 2} \pm \mathbf{1 1} \\
{[0.214 \pm 0.019]}\end{array}$ & $\begin{array}{c}\mathbf{2 5 5} \pm \mathbf{1 2} \\
{[0.213 \pm 0.011]}\end{array}$ & $\begin{array}{c}\mathbf{3 9 8} \pm \mathbf{1 0} \\
{[0.135 \pm 0.013]}\end{array}$ \\
\hline DMSO & $\begin{array}{c}\mathbf{1 2 2} \pm \mathbf{6} \\
{[0.098 \pm 0.005]}\end{array}$ & $\begin{array}{c}115 \pm 3 \\
{[0.112 \pm 0.006]}\end{array}$ & $\begin{array}{c}\mathbf{1 3 4} \pm \mathbf{7} \\
{[0.215 \pm 0.012]}\end{array}$ & $\begin{array}{c}\mathbf{1 2 4} \pm \mathbf{7} \\
{[0.219 \pm 0.030]}\end{array}$ & $\begin{array}{c}\mathbf{2 4 9} \pm \mathbf{1 1} \\
{[0.247 \pm 0.017]}\end{array}$ \\
\hline
\end{tabular}

Table 6. The influence of the organic solvent on the formation of the 1L6 NPs in the presence of five surfactants.

\begin{tabular}{|c|c|c|c|c|c|}
\hline \multirow{3}{*}{ Organic Solvent } & \multicolumn{5}{|c|}{ Surfactant } \\
\hline & Tween 20 & Tween 80 & Kolliphor P188 & Brij 010 & Mowiol 4-88 \\
\hline & \multicolumn{5}{|c|}{$\operatorname{MPD}(\mathrm{nm}) \pm \mathrm{SD}$} \\
\hline DMI & $\begin{array}{c}\mathbf{1 3 2} \pm \mathbf{7} \\
{[0.152 \pm 0.032]}\end{array}$ & $\begin{array}{c}\mathbf{1 6 8} \pm \mathbf{5} \\
{[0.104 \pm 0.010]}\end{array}$ & $\begin{array}{c}\mathbf{1 5 5} \pm \mathbf{3} \\
{[0.219 \pm 0.019]}\end{array}$ & $\begin{array}{c}\mathbf{1 3 6} \pm \mathbf{1} \\
{[0.145 \pm 0.098]}\end{array}$ & $\begin{array}{c}\mathbf{2 1 8} \pm \mathbf{6} \\
{[0.102 \pm 0.056]}\end{array}$ \\
\hline DMF & $\begin{array}{c}\mathbf{2 1 5} \pm \mathbf{9} \\
{[0.139 \pm 0.010]}\end{array}$ & $\begin{array}{c}193 \pm 7 \\
{[0.103 \pm 0.030]}\end{array}$ & $\begin{array}{c}\mathbf{1 9 4} \pm \mathbf{1 0} \\
{[0.213 \pm 0.010]}\end{array}$ & $\begin{array}{c}\mathbf{2 1 3} \pm \mathbf{1 0} \\
{[0.219 \pm 0.012]}\end{array}$ & $\begin{array}{c}\mathbf{2 8 8} \pm \mathbf{1 0} \\
{[0.135 \pm 0.017]}\end{array}$ \\
\hline DMSO & $\begin{array}{c}\mathbf{1 2 3} \pm \mathbf{9} \\
{[0.223 \pm 0.011]}\end{array}$ & $\begin{array}{c}\mathbf{1 4 4} \pm \mathbf{8} \\
{[0.212 \pm 0.013]}\end{array}$ & $\begin{array}{c}\mathbf{1 0 1} \pm \mathbf{4} \\
{[0.229 \pm 0.011]}\end{array}$ & $\begin{array}{c}\mathbf{1 1 2} \pm \mathbf{4} \\
{[0.203 \pm 0.010]}\end{array}$ & $\begin{array}{c}\mathbf{1 6 4} \pm \mathbf{9} \\
{[0.219 \pm 0.010]}\end{array}$ \\
\hline Acetone & $\begin{array}{c}\mathbf{2 5 2} \pm \mathbf{1 2} \\
{[0.216 \pm 0.017]}\end{array}$ & $\begin{array}{c}\mathbf{2 8 0} \pm \mathbf{1 4} \\
{[0.239 \pm 0.019]}\end{array}$ & $\begin{array}{c}\mathbf{2 7 8} \pm \mathbf{1 1} \\
{[0.293 \pm 0.021]}\end{array}$ & $\begin{array}{c}\mathbf{2 9 3} \pm \mathbf{1 1} \\
{[0.311 \pm 0.016]}\end{array}$ & $\begin{array}{c}323 \pm 13 \\
{[0.245 \pm 0.031]}\end{array}$ \\
\hline
\end{tabular}

Table 7. The influence of the organic solvent on the formation of the 4F4 NPs in the presence of five surfactants.

\begin{tabular}{|c|c|c|c|c|c|}
\hline \multirow{3}{*}{ Organic Solvent } & \multicolumn{5}{|c|}{ Surfactant } \\
\hline & Tween 20 & Tween 80 & Kolliphor P188 & Brij 010 & Mowiol 4-88 \\
\hline & \multicolumn{5}{|c|}{$\operatorname{MPD}(\mathrm{nm}) \pm \mathrm{SD} \quad[\mathrm{PDI}] \pm \mathrm{SD}$} \\
\hline DMI & $\begin{array}{c}\mathbf{1 5 8} \pm \mathbf{7} \\
{[0.111 \pm 0.006]}\end{array}$ & $\begin{array}{c}\mathbf{1 5 7} \pm \mathbf{7} \\
{[0.091 \pm 0.003]}\end{array}$ & $\begin{array}{c}\mathbf{1 1 1} \pm \mathbf{1} \\
{[0.054 \pm 0.012]}\end{array}$ & $\begin{array}{c}\mathbf{1 6 3} \pm \mathbf{1 0} \\
{[0.299 \pm 0.013]}\end{array}$ & $\begin{array}{c}\mathbf{1 7 3} \pm \mathbf{9} \\
{[0.117 \pm 0.009]}\end{array}$ \\
\hline DMF & $\begin{array}{c}\mathbf{1 3 8} \pm \mathbf{3} \\
{[0.116 \pm 0.011]}\end{array}$ & $\begin{array}{c}\mathbf{1 2 4} \pm \mathbf{2} \\
{[0.126 \pm 0.004]}\end{array}$ & $\begin{array}{c}135 \pm \mathbf{3} \\
{[0.132 \pm 0.004]}\end{array}$ & $\begin{array}{c}\mathbf{1 2 3} \pm \mathbf{2} \\
{[0.119 \pm 0.032]}\end{array}$ & $\begin{aligned} \mathbf{2 0 4} & \pm \mathbf{2} \\
{[0.103} & \pm 0.008]\end{aligned}$ \\
\hline DMSO & $\begin{array}{c}\mathbf{9 3} \pm \mathbf{4} \\
{[0.302 \pm 0.023]}\end{array}$ & $\begin{array}{c}\mathbf{6 0} \pm \mathbf{1} \\
{[0.240 \pm 0.001]}\end{array}$ & $\begin{array}{c}100 \pm \mathbf{3} \\
{[0.260 \pm 0.001]}\end{array}$ & $\begin{array}{c}\mathbf{5 6} \pm \mathbf{2} \\
{[0.132 \pm 0.078]}\end{array}$ & $\begin{array}{c}\mathbf{9 8} \pm \mathbf{1} \\
{[0.110 \pm 0.010]}\end{array}$ \\
\hline
\end{tabular}

$\checkmark$ Partially aggregated samples.

Table 8. The influence of the organic solvent on the formation of 8L6 NPs in the presence of five surfactants.

\begin{tabular}{|c|c|c|c|c|c|}
\hline \multirow{3}{*}{ Organic Solvent } & \multicolumn{5}{|c|}{ Surfactant } \\
\hline & Tween 20 & Tween 80 & Kolliphor P188 & Brij 010 & Mowiol 4-88 \\
\hline & \multicolumn{5}{|c|}{$\mathrm{MPD}(\mathrm{nm}) \pm \mathrm{SD} \quad[\mathrm{PDI}] \pm \mathrm{SD}$} \\
\hline DMI & $\begin{array}{c}\mathbf{1 5 9} \pm \mathbf{3} \\
{[0.131 \pm 0.003]}\end{array}$ & $\begin{array}{c}\mathbf{1 6 2} \pm \mathbf{1 5} \\
{[0.101 \pm 0.002]}\end{array}$ & $\begin{array}{c}\mathbf{9 8} \pm \mathbf{2} \\
{[0.116 \pm 0.009]}\end{array}$ & $\begin{array}{c}\mathbf{1 6 6} \pm \mathbf{5} \\
{[0.088 \pm 0.001]}\end{array}$ & $\begin{array}{c}\mathbf{1 4 4} \pm \mathbf{3} \\
{[0.076 \pm 0.006]}\end{array}$ \\
\hline DMF & $\begin{array}{c}\mathbf{1 8 7} \pm \mathbf{4} \\
{[0.180 \pm 0.006]}\end{array}$ & $\begin{array}{c}\mathbf{1 7 6} \pm \mathbf{1 0} \\
{[0.231 \pm 0.013]}\end{array}$ & $\begin{array}{c}186 \pm \mathbf{8} \\
(\mathrm{P}-\mathrm{I}) 56 \% \\
575 \pm \mathbf{2 4} \\
(\mathrm{P}-\mathrm{II}) 44 \% \\
{[0.456 \pm 0.018]}\end{array}$ & $\begin{array}{c}\mathbf{1 7 0} \pm \mathbf{1 0} \\
{[0.193 \pm 0.011]}\end{array}$ & $\begin{array}{c}\mathbf{1 6 9} \pm \mathbf{8} \\
{[0.131 \pm 0.012]}\end{array}$ \\
\hline DMSO & $\begin{array}{c}\mathbf{7 0} \pm \mathbf{5} \\
{[0.115 \pm 0.008]}\end{array}$ & $\begin{array}{c}135 \pm \mathbf{8} \\
{[0.171 \pm 0.011]}\end{array}$ & $\begin{array}{c}\mathbf{8 5} \pm \mathbf{3} \\
{[0.150 \pm 0.006]}\end{array}$ & $\begin{array}{c}73 \pm \mathbf{6} \\
{[0.273 \pm 0.016]} \\
\end{array}$ & $\begin{array}{c}\mathbf{9 6} \pm \mathbf{9} \\
{[0.214 \pm 0.018]}\end{array}$ \\
\hline Acetone & $\begin{array}{c}\mathbf{1 9 2} \pm \mathbf{5} \\
{[0.105 \pm 0.003]}\end{array}$ & $\begin{array}{c}235 \pm 10 \\
{[0.112 \pm 0.008]}\end{array}$ & $\begin{array}{c}\mathbf{1 7 2} \pm \mathbf{3} \\
{[0.113 \pm 0.006]}\end{array}$ & $\begin{array}{c}\mathbf{2 0 3} \pm \mathbf{9} \\
{[0.254 \pm 0.016]}\end{array}$ & $\begin{array}{c}\mathbf{2 8 3} \pm \mathbf{1 1} \\
{[0.183 \pm 0.012]}\end{array}$ \\
\hline
\end{tabular}




\subsubsection{The Influence of the $\mathrm{O} / \mathrm{W}$ Ratio}

For these experiments two neutral AABB polymers, 1F6 and 4F4, and two of eight surfactants were used. The parameters (invariable and variable) of the NPs fabrication process are given in the able below:

\begin{tabular}{|c|c|}
\hline \multicolumn{2}{|c|}{ Parameters of the Process } \\
\hline Invariable & Variable \\
\hline $\begin{array}{l}\text { - } \text { solvent-DMI } \\
\text { - } \text { concentration of the polymer in organic phase- }-6.0 \mathrm{mg} / \mathrm{mL} \\
\text { - } \text { concentration of surfactant in the water phase- }-5.0 \mathrm{mg} / \mathrm{mL} \\
\text { - } \text { organic phase dropping rate-12 drops } / \mathrm{min} \\
\text { - } \quad \text { stirring rate of the water phase- }-700 \mathrm{rpm} \text {. }\end{array}$ & $\begin{array}{ll}\text { - } & \mathrm{O} / \mathrm{W} \text { ratio-1:2, 1:5, 1:10, 1:20 } \\
\text { - } & \text { polymers (two)-1F6 and 4F4 } \\
\text { - } & \text { surfactants (two)-Tween } 20 \text { and Brij } 010 .\end{array}$ \\
\hline
\end{tabular}

The conditions of the NPs fabrication were as follows: the solvent: DMI; polymer concentration in the organic phase: $6.0 \mathrm{mg} / \mathrm{mL}$; surfactant concentration in the water phase: $5.0 \mathrm{mg} / \mathrm{mL}$; the O/W ratios: 1:2, 1:5, 1:10, and 1:20, accordingly; the organic phase dropping rate: $12 \mathrm{drops} / \mathrm{min}$; and the stirring rate: $700 \mathrm{rpm}$. The results obtained for the selected AABB polymers $1 \mathrm{~F} 6$ and $4 \mathrm{~F} 4$ using two surfactants in terms of the MPD and PDI of the NPs are listed in Table 9.

Table 9. The influence of the ratio of organic phase/water phase $(\mathrm{O} / \mathrm{W})$ on the formation of the NPs from $1 \mathrm{~F} 6$ and $4 \mathrm{~F} 4$.

\begin{tabular}{|c|c|c|c|c|}
\hline \multirow{5}{*}{ O:W } & \multicolumn{4}{|c|}{ Surfactant } \\
\hline & Tween 20 & Brij 010 & Tween 20 & Brij 010 \\
\hline & \multicolumn{4}{|c|}{ Polymer } \\
\hline & \multicolumn{2}{|c|}{ 1F6 } & \multicolumn{2}{|c|}{$4 \mathrm{~F} 4$} \\
\hline & & $\mathrm{MPD}(\mathrm{nm}) \pm \mathrm{SD}$ & {$[\mathrm{PDI}] \pm \mathrm{SD}$} & \\
\hline $1: 2$ & $\begin{array}{c}449 \pm 23 \\
(\mathrm{P}-\mathrm{I}) 68 \% \\
2569 \pm 286 \\
(\mathrm{P}-\mathrm{II}) 32 \% \\
{[0.468 \pm 0.053]}\end{array}$ & $\begin{array}{c}322 \pm 9 \\
{[0.258 \pm 0.007]}\end{array}$ & $\begin{array}{c}483 \pm 19 \\
(\mathrm{P}-\mathrm{I}) 73 \% \\
3534 \pm \mathbf{2 1 8} \\
(\mathrm{P}-\mathrm{II}) 27 \% \\
{[0.468 \pm 0.059]}\end{array}$ & $\begin{array}{c}213 \pm \mathbf{8} \\
{[0.246 \pm 0.009]}\end{array}$ \\
\hline $1: 5$ & $\begin{array}{c}\mathbf{1 7 7} \pm \mathbf{5} \\
{[0.118 \pm 0.014]}\end{array}$ & $\begin{array}{c}237 \pm 6 \\
{[0.225 \pm 0.009]}\end{array}$ & $\begin{array}{c}166 \pm \mathbf{6} \\
{[0.128 \pm 0.012]}\end{array}$ & $\begin{array}{c}153 \pm \mathbf{5} \\
{[0.218 \pm 0.007]}\end{array}$ \\
\hline $1: 10$ & $\begin{array}{c}143 \pm 6 \\
{[0.123 \pm 0.019]}\end{array}$ & $\begin{array}{c}160 \pm \mathbf{1 0} \\
{[0.210 \pm 0.005]}\end{array}$ & $\begin{array}{c}158 \pm 7 \\
{[0.111 \pm 0.006]}\end{array}$ & $\begin{array}{c}163 \pm 10 \\
{[0.299 \pm 0.013]}\end{array}$ \\
\hline $1: 20$ & $\begin{array}{c}138 \pm \mathbf{6} \\
{[0.102 \pm 0.020]}\end{array}$ & $\begin{array}{c}159 \pm \mathbf{9} \\
{[0.259 \pm 0.012]}\end{array}$ & $\begin{array}{c}\mathbf{1 6 5} \pm \mathbf{5} \\
{[0.158 \pm 0.008]}\end{array}$ & $\begin{array}{c}\mathbf{1 6 9} \pm \mathbf{8} \\
{[0.241 \pm 0.015]}\end{array}$ \\
\hline
\end{tabular}

\subsubsection{The Influence of the Organic Phase Dropping Rate to the Water Phase}

In these experiments two neutral AABB polymers, 1F6 and 4F4, and two of eight surfactants were used. The parameters (invariable and variable) of the NPs fabrication process are given in the table below:

\begin{tabular}{|c|c|}
\hline \multicolumn{2}{|c|}{ Parameters of the Process } \\
\hline Invariable & Variable \\
\hline $\begin{array}{l}\text { - } \text { solvent-DMI } \\
\text { - } \text { concentration of the polymer in organic phase- }-6.0 \mathrm{mg} / \mathrm{mL} \\
\text { - } \text { concentration of surfactant in the water phase }-5.0 \mathrm{mg} / \mathrm{mL} \\
\text { - } \mathrm{O} / \mathrm{W} \text { ratio-1:10 } \\
\text { - } \\
\text { stirring rate of the water phase }-700 \mathrm{rpm} \text {. }\end{array}$ & $\begin{array}{ll}\text { - } & \text { polymers (two)-1F6 and } \mathbf{4 F 4} \\
\text { - } & \text { surfactants (two)-Triton X-100 and Brij } 010 \\
\text { - } & \text { Organic phase dropping rate-2,6 and } 12 \text { drops/min }\end{array}$ \\
\hline
\end{tabular}


The conditions of the NPs fabrication were as follows: the solvent: DMI; polymer concentration in the organic phase: $6.0 \mathrm{mg} / \mathrm{mL}$, surfactant concentration in the water phase: $5.0 \mathrm{mg} / \mathrm{mL}$; the organic phase dropping rates: 2,6 , and 12 drops/min, accordingly; the $O / W$ ratio: 1:10; and the water phase stirring rate: $700 \mathrm{rpm}$. The results obtained for the selected AABB polymers 1F6 and 4F4 using two surfactants in terms of the MPD of the NPs are given in Figure 6.
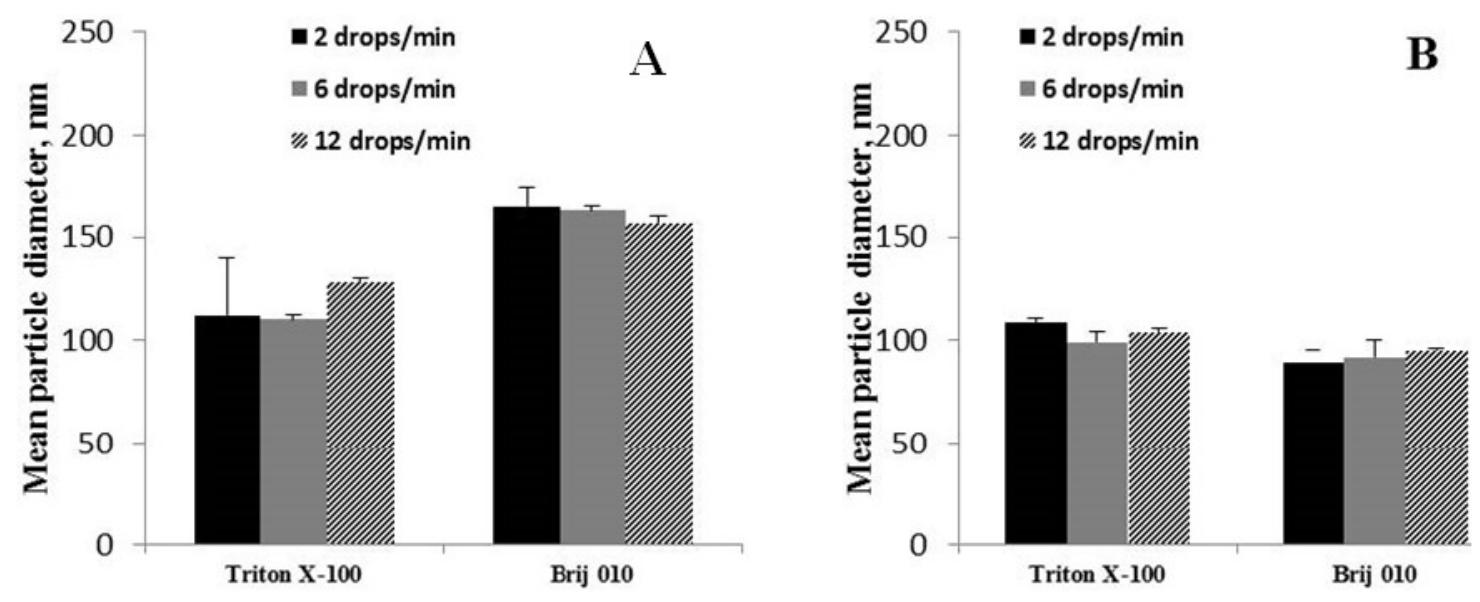

Figure 6. The influence of the dropping rate of the organic phase to the water phase on the mean diameter of 1 F6 (A) and 4F4 (B) NPs.

\subsubsection{The Influence of the Stirring Rate of the Water Phase}

For these experiments two neutral AABB polymers, $1 \mathrm{~F} 6$ and $4 \mathbf{F 4}$, and three of eight surfactants were used. The parameters (invariable and variable) of the NPs fabrication process are given in the table below:

\begin{tabular}{|c|c|}
\hline \multicolumn{2}{|c|}{ Parameters of the Process } \\
\hline Invariable & Variable \\
\hline $\begin{array}{l}\text { - } \\
\text { - } \text { colvent-DMI } \\
\text { phase- }-6.0 \mathrm{mg} / \mathrm{mL} \\
\text { - concentration of surfactant in the water } \\
\text { phase- } 5.0 \mathrm{mg} / \mathrm{mL} \\
\text { - } \mathrm{O} / \mathrm{W} \text { ratio- } 1: 10 \\
\text { - } \text { organic phase dropping rate- } 12 \text { drops } / \mathrm{min}\end{array}$ & 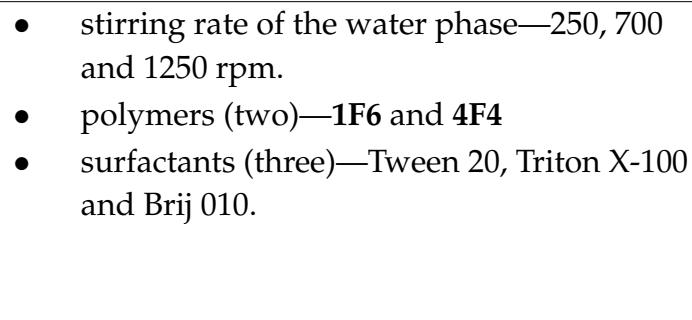 \\
\hline
\end{tabular}

The conditions of the NPs fabrication were as follows: the solvent: DMI; polymer concentration in the organic phase: $6.0 \mathrm{mg} / \mathrm{mL}$; surfactant concentration in the water phase: $5.0 \mathrm{mg} / \mathrm{mL}$; the O/W ratio: 1:10; the organic phase dropping rate $12 \mathrm{drops} / \mathrm{min}$; and the stirring rates 250, 700 and $1250 \mathrm{rpm}$, accordingly. The results obtained for the selected AABB polymers 1F6 and 4F4 using three surfactants in terms of the MPD of the NPs are given in Figure 7. 

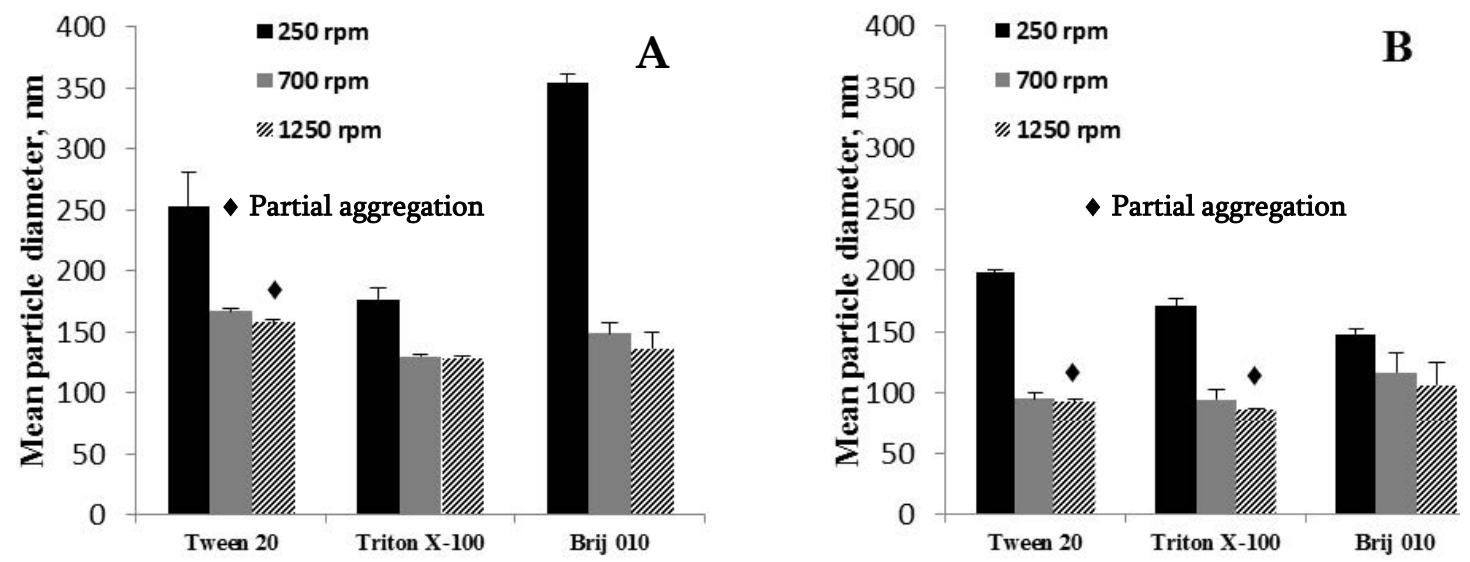

Figure 7. The influence of the stirring rate of the water phase on the mean diameter of the $\mathbf{1 F 6}(\mathbf{A})$ and 4F4 (B) NPs.

\subsection{Modified method of the NPs fabrication}

Within the present study we have elaborated a modified nanoprecipitation method, according to which the surfactant was dissolved in the organic solvent and added dropwise to the aqueous phase, i.e., pure water. All the neutral AABB polymers 1F6, 1L6, 4F4 and 8L6, and five of eight surfactants were included in these experiments. The parameters (invariable and variable) of the NPs fabrication process are given in table below:

\begin{tabular}{|c|c|}
\hline \multicolumn{2}{|c|}{ Parameters of the Process } \\
\hline Invariable & Variable \\
\hline 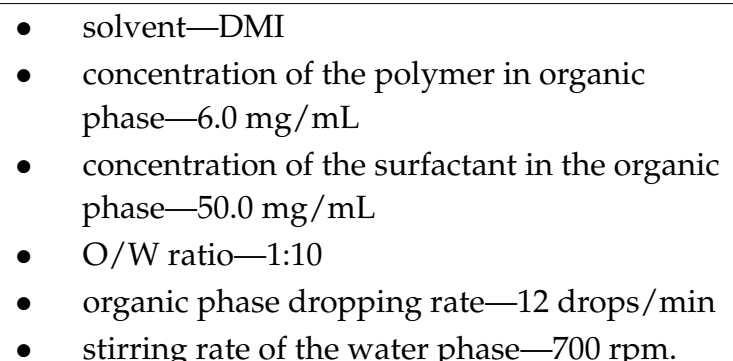 & $\begin{array}{l}\text { - } \quad \text { polymers (four) -1F6, 1L6, 4F4 and 8L6 } \\
\text { - } \quad \text { surfactants (five) - Tween 20, Triton X-100, } \\
\text { Brij 010, Mowiol 4-88 and Mowiol 8-88 }\end{array}$ \\
\hline
\end{tabular}

The conditions of the NPs fabrication were as follows: the solvent: DMI; the polymer concentration in the organic phase: $6.0 \mathrm{mg} / \mathrm{mL}$; the surfactant concentration in the organic phase: $50.0 \mathrm{mg} / \mathrm{mL}$; the $\mathrm{O} / \mathrm{W}$ ratio: 1:10; the organic phase dropping rate: $12 \mathrm{drops} / \mathrm{min}$; and the stirring rate of the water phase: $700 \mathrm{rpm}$. The results obtained for all the AABB polymers using five surfactants in terms of the MPD and PDI of the NPs are listed in Tables 10-13.

Table 10. The comparison of the PEU 1F6 NPs prepared by nanoprecipitation (NM) and modified nanoprecipitation (MNM) methods.

\begin{tabular}{|c|c|c|c|c|c|}
\hline \multirow{3}{*}{ Method } & \multicolumn{5}{|c|}{ Surfactant } \\
\hline & Tween 20 & Triton X-100 & Brij 010 & Mowiol 4-88 & Mowiol 8-88 \\
\hline & \multicolumn{5}{|c|}{$\operatorname{MPD}(\mathrm{nm}) \pm \mathrm{SD} \quad[\mathrm{PDI}] \pm \mathrm{SD}$} \\
\hline $\mathrm{NM}$ & $\begin{array}{c}\mathbf{1 4 3} \pm \mathbf{6} \\
{[0.123 \pm 0.019]}\end{array}$ & $\begin{array}{c}148 \pm \mathbf{6} \\
{[0.116 \pm 0.004]}\end{array}$ & $\begin{array}{c}160 \pm \mathbf{1 0} \\
{[0.268 \pm 0.009]}\end{array}$ & $\begin{array}{c}321 \pm \mathbf{4} \\
{[0.053 \pm 0.015]}\end{array}$ & $\begin{array}{c}328 \pm \mathbf{2} \\
{[0.075 \pm 0.019]}\end{array}$ \\
\hline MNM & $\begin{array}{c}\mathbf{1 2 1} \pm \mathbf{4} \\
{[0.230 \pm 0.024]}\end{array}$ & $\begin{array}{c}\mathbf{1 1 3} \pm \mathbf{5} \\
{[0.180 \pm 0.011]}\end{array}$ & $\begin{array}{c}108 \pm \mathbf{3} \\
{[0.213 \pm 0.006]}\end{array}$ & $\begin{array}{c}222 \pm \mathbf{7} \\
{[0.092 \pm 0.020]}\end{array}$ & $\begin{array}{c}199 \pm \mathbf{4} \\
{[0.087 \pm 0.014]}\end{array}$ \\
\hline
\end{tabular}


Table 11. The comparison of the PEU 1L6 NPs prepared by nanoprecipitation (NM) and modified nanoprecipitation (MNM) methods.

\begin{tabular}{|c|c|c|c|c|c|}
\hline \multirow{3}{*}{ Method } & \multicolumn{5}{|c|}{ Surfactant } \\
\hline & Tween 20 & Triton X-100 & Brij 010 & Mowiol 4-88 & Mowiol 8-88 \\
\hline & \multicolumn{5}{|c|}{$\operatorname{MPD}(\mathrm{nm}) \pm \mathrm{SD}$} \\
\hline NM & $\begin{array}{c}132 \pm \mathbf{7} \\
{[0.152 \pm 0.032]}\end{array}$ & $\begin{array}{c}\mathbf{1 4 0} \pm \mathbf{8} \\
{[0.172 \pm 0.091]}\end{array}$ & $\begin{array}{c}\mathbf{1 3 6} \pm \mathbf{1} \\
{[0.145 \pm 0.098]}\end{array}$ & $\begin{array}{c}\mathbf{2 1 8} \pm \mathbf{6} \\
{[0.102 \pm 0.056]}\end{array}$ & $\begin{array}{c}\mathbf{2 6 0} \pm \mathbf{1 0} \\
{[0.192 \pm 0.086]}\end{array}$ \\
\hline MNM & $\begin{array}{c}\mathbf{1 1 2} \pm \mathbf{5} \\
{[0.102 \pm 0.016]}\end{array}$ & $\begin{array}{c}118 \pm 2 \\
(\mathrm{P}-\mathrm{I}) 70 \% \\
4093 \pm 684 \\
(\mathrm{P}-\mathrm{II}) 20 \% \\
{[0.602 \pm 0.016]}\end{array}$ & $\begin{array}{c}\mathbf{1 1 1} \pm \mathbf{6} \\
(\mathrm{P}-\mathrm{I}) 52 \% \\
\mathbf{2 7 2 6} \pm \mathbf{2 6 5} \\
(\mathrm{P}-\mathrm{II}) 48 \% \\
{[0.807 \pm 0.023]}\end{array}$ & $\begin{array}{c}\mathbf{1 4 3} \pm \mathbf{2} \\
(\mathrm{P}-\mathrm{I}) \mathbf{7 0 \%} \\
\mathbf{3 2 5 0} \pm \mathbf{1 8 2} \\
(\mathrm{P}-\mathrm{II}) 30 \% \\
{[0.563 \pm 0.005]}\end{array}$ & $\begin{array}{c}\mathbf{2 1 2} \pm \mathbf{5} \\
{[0.293 \pm 0.033]}\end{array}$ \\
\hline
\end{tabular}

Table 12. The comparison of the PEA 4F4 NPs prepared by nanoprecipitation (NM) and modified nanoprecipitation (MNM) methods.

\begin{tabular}{|c|c|c|c|c|c|}
\hline \multirow{3}{*}{ Method } & \multicolumn{5}{|c|}{ Surfactant } \\
\hline & Tween 20 & Triton X-100 & Brij 010 & Mowiol 4-88 & Mowiol 8-88 \\
\hline & \multicolumn{5}{|c|}{$\operatorname{MPD}(\mathrm{nm}) \pm \mathrm{SD}$} \\
\hline NM & $\begin{array}{c}158 \pm \mathbf{7} \\
{[0.111 \pm 0.006]}\end{array}$ & $\begin{array}{c}139 \pm 7 \\
{[0.121 \pm 0.009]}\end{array}$ & $\begin{array}{c}\mathbf{1 6 3} \pm \mathbf{1 0} \\
{[0.299 \pm 0.013]}\end{array}$ & $\begin{array}{c}\mathbf{1 7 3} \pm \mathbf{9} \\
{[0.117 \pm 0.009]}\end{array}$ & $\begin{array}{c}\mathbf{2 4 0} \pm \mathbf{1 0} \\
{[0.224 \pm 0.008]}\end{array}$ \\
\hline MNM & $\begin{array}{c}\mathbf{8 5} \pm \mathbf{2} \\
{[0.125 \pm 0.002]}\end{array}$ & $\begin{array}{c}\mathbf{8 5} \pm \mathbf{6} \\
{[0.231 \pm 0.014]}\end{array}$ & $\begin{array}{c}\mathbf{7 9} \pm \mathbf{4} \\
{[0.157 \pm 0.006]}\end{array}$ & $\begin{array}{c}129 \pm \mathbf{8} \\
{[0.212 \pm 0.006]}\end{array}$ & $\begin{array}{c}\mathbf{2 1 1} \pm \mathbf{1 2} \\
{[0.214 \pm 0.016]}\end{array}$ \\
\hline
\end{tabular}

Table 13. The comparison of the PEA 8L6 NPs prepared by nanoprecipitation (NM) and modified nanoprecipitation (MNM) methods.

\begin{tabular}{|c|c|c|c|c|c|}
\hline \multirow{3}{*}{ Method } & \multicolumn{5}{|c|}{ Surfactant } \\
\hline & Tween 20 & Triton X-100 & Brij 010 & Mowiol 4-88 & Mowiol 8-88 \\
\hline & \multicolumn{5}{|c|}{$\operatorname{MPD}(\mathrm{nm}) \pm \mathrm{SD}$} \\
\hline NM & $\begin{array}{c}\mathbf{1 5 9} \pm \mathbf{3} \\
{[0.131 \pm 0.003]}\end{array}$ & $\begin{array}{c}\mathbf{1 5 4} \pm \mathbf{9} \\
{[0.090 \pm 0.003]}\end{array}$ & $\begin{array}{c}\mathbf{1 6 6} \pm \mathbf{5} \\
{[0.088 \pm 0.001]}\end{array}$ & $\begin{array}{c}\mathbf{1 4 4} \pm \mathbf{3} \\
{[0.076 \pm 0.006]}\end{array}$ & $\begin{array}{c}\mathbf{1 8 1} \pm \mathbf{6} \\
{[0.095 \pm 0.003]}\end{array}$ \\
\hline MNM & $\begin{array}{c}\mathbf{1 1 1} \pm \mathbf{9} \\
{[0.222 \pm 0.005]}\end{array}$ & $\begin{array}{c}132 \pm 4 \\
{[0.089 \pm 0.006]}\end{array}$ & $\begin{array}{c}93 \pm \mathbf{6}(\mathrm{P}-\mathrm{I}) \\
51 \% \\
\mathbf{2 3 2 9} \pm \mathbf{2 2 5} \\
(\mathrm{P}-\mathrm{II}) 49 \% \\
{[0.331 \pm 0.082]}\end{array}$ & $\begin{array}{c}143 \pm 3(\mathrm{P}-\mathrm{I}) \\
65 \% \\
3364 \pm 272 \\
(\mathrm{P}-\mathrm{II}) 35 \% \\
{[0.413 \pm 0.020]}\end{array}$ & $\begin{array}{c}311 \pm 10(\mathrm{P}-\mathrm{I}) \\
67 \% \\
3189 \pm 195 \\
(\mathrm{P}-\mathrm{II}) 33 \% \\
{[0.412 \pm 0.052]}\end{array}$ \\
\hline
\end{tabular}

P-population of the NPs.

\subsection{ZP of the NPs}

In parallel with the particle size (MPD), the zeta-potentials (ZP) of the NPs made of all four neutral AABB polymers using three of eight surfactants were determined. The parameters (invariable and variable) of the NPs fabrication process are given in the table below:

\begin{tabular}{lll}
\hline \multicolumn{3}{c}{ Parameters of the Process } \\
\hline \multicolumn{1}{c}{ Invariable } & \multicolumn{1}{c}{ Variable } \\
\hline - & solvent-DMI & \multicolumn{1}{c}{$\begin{array}{l}\text { polymers (four)-1F6, 1L6, 4F4 and 8L6 } \\
\text { surfactants (three)-Tween 20, Tween } 80 \\
\text { and Brij 010 }\end{array}$} \\
- & content of the surfactant in the organic phase $-5.0 \mathrm{mg} / \mathrm{mL}$ \\
- & O/W ratio-1:10 \\
- & organic phase dropping rate-12 drops $/ \mathrm{min}$ \\
- & stirring rate of the water phase-700 rpm. \\
\hline
\end{tabular}


The conditions of the NPs fabrication were as follows: the solvent: DMI; polymer concentration in the organic phase: $6.0 \mathrm{mg} / \mathrm{mL}$; surfactant concentration in the organic phase: $5.0 \mathrm{mg} / \mathrm{mL}$; the O/W ratio: 1:10; the organic phase dropping rate: $12 \mathrm{drops} / \mathrm{min}$; and the stirring rate of the water phase: $700 \mathrm{rpm}$. The ZP of the obtained NPs are listed in Table 14.

Table 14. ZP of the NPs made of AABB polymers.

\begin{tabular}{cccc}
\hline \multirow{2}{*}{ Polymer } & \multicolumn{3}{c}{ Surfactant } \\
\cline { 2 - 4 } & Tween 20 & Tween $\mathbf{8 0}$ & Brij 010 \\
\cline { 2 - 4 } & & Zeta-potential $\mathbf{( m V )} \pm \mathbf{S D}$ \\
\hline 1F6 & $-2.47 \pm 2.25$ & $-1.58 \pm 1.39$ & $-7.08 \pm 2.55$ \\
1L6 & $-2.97 \pm 1.64$ & $-2.89 \pm 2.78$ & $-5.15 \pm 1.62$ \\
4F4 & $-2.44 \pm 1.16$ & $-2.49 \pm 1.07$ & $-9.14 \pm 1.51$ \\
8L6 & $-12.50 \pm 1.99$ & $-8.50 \pm 2.68$ & $-7.70 \pm 2.29$ \\
\hline
\end{tabular}

\subsection{Fabrication of Positively Charged NPs}

To impart a positive charge to the NPs, the neutral AABB polymer (viz. the PEA 8L6) was blended with the cationic AABB polymer 8R6: $6.0 \mathrm{mg}$ of $\mathbf{8 L 6}$ were dissolved in $1.0 \mathrm{~mL}$ of the organic solvents (DMSO) and 8 R6 was added in the amount of $5.0,10.0,20.0,30.0$, or $50.0 \mathrm{wt} \%$ of the $8 \mathbf{L} 6(0.3,0.6,1.2$, 1.8 , or $3.0 \mathrm{mg}$ ), respectively. The organic phase containing the polymeric blend was dropped to the water phase for fabricating the positively charged NPs. Tween 20 was used as a surfactant in these experiments. The parameters (invariable and variable) of the NPs fabrication process are given in the table below:

\begin{tabular}{llc}
\hline \multicolumn{2}{c}{ Parameters of the Process } \\
\hline \multicolumn{1}{c}{ Invariable } & \multicolumn{1}{c}{ Variable } \\
\hline - & \multicolumn{1}{c}{ polymer-8L6 } & \multicolumn{1}{c}{ cationic polymer 8R6-5.0, 10.0, 20.0, 30.0, } \\
- & concentration of the polymer in organic phase- $-6.0 \mathrm{mg} / \mathrm{mL}$ & \\
- & concentration of surfactant Tween 20 in the water phase- $-5.0 \mathrm{mg} / \mathrm{mL}$ & \\
- & O/W ratio-1:10 \\
- & organic phase dropping rate-12 drops $/ \mathrm{min}$ \\
- & stirring rate of the water phase-700 rpm. \\
\hline
\end{tabular}

The conditions of the NPs fabrication were as follows: the solvent: DMSO; the polymer concentration in the organic phase: $6.0 \mathrm{mg} / \mathrm{mL}$ of $8 \mathbf{L 6}$ plus $0.3,0.61 .2,1.8$, or $3.0 \mathrm{mg}$ of $\mathbf{8 R 6}$; the surfactant (Tween 20) concentration in the water phase: $5.0 \mathrm{mg} / \mathrm{mL}$; the $\mathrm{O} / \mathrm{W}$ ratio: $1: 10$; the organic phase dropping rate: $12 \mathrm{drops} / \mathrm{min}$; and the stirring rate of the water phase: $700 \mathrm{rpm}$. The ZP of the obtained positively charged NPs are listed in Table 15.

Table 15. The ZP of the NPs made of 8L6/8R6 blends.

\begin{tabular}{ccc}
\hline Polymer & 8R6 Content $(\%, w / w)$ & Zeta-Potential $(\mathbf{m V}) \pm$ SD \\
\hline 8L6 & 0 & $-1.73 \pm 0.6$ \\
\hline & 5 & $+19.6 \pm 3.6$ \\
8L6/8R6 & 10 & $+23.2 \pm 4.7$ \\
& 20 & $+25.8 \pm 2.7$ \\
& 30 & $+27.2 \pm 3.2$ \\
& 50 & $+28.0 \pm 4.9$ \\
\hline
\end{tabular}

\subsection{Stability of the NPS}

The negatively charged NPs (as prepared after the nanoprecipitation) listed in Table 14 were studied for stability upon storage. The NPs MPD and PDI were measured right after the fabrication. After this the suspensions were separated into two parts; one part was stored at r.t. $\left(23-25^{\circ} \mathrm{C}\right)$ and 
another part was refrigerated at $4-5{ }^{\circ} \mathrm{C}$. After predetermined times the samples were thoroughly shaken and analyzed for the MPD and PDI. The results obtained for the NPs made of all four AABB polymers are listed in Tables 16-19.

Table 16. The stability of the 1F6 NPs upon storage.

\begin{tabular}{|c|c|c|c|c|c|c|}
\hline \multirow{4}{*}{ Time } & \multicolumn{6}{|c|}{ Surfactant } \\
\hline & Tween 20 & Tween 80 & Brij 010 & Tween 20 & Tween 80 & Brij 010 \\
\hline & \multicolumn{6}{|c|}{$\mathrm{MPD}(\mathrm{nm}) \pm \mathrm{SD}$} \\
\hline & \multicolumn{3}{|c|}{ At r.t. $\left(23-25^{\circ} \mathrm{C}\right)$} & \multicolumn{3}{|c|}{ Refrigerated $\left(4-5{ }^{\circ} \mathrm{C}\right)$} \\
\hline $\begin{array}{l}\text { Freshly } \\
\text { prepared }\end{array}$ & $143 \pm 6$ & $156 \pm 4$ & $160 \pm 10$ & $143 \pm 6$ & $156 \pm 4$ & $160 \pm 10$ \\
\hline A week later & $\begin{array}{c}1688 \pm \mathbf{6 2 8} \\
(\mathrm{P}-\mathrm{I}) 55 \% \\
\mathbf{2 3 8} \pm \mathbf{7 5} \\
(\mathrm{P}-\mathrm{II}) 45 \%\end{array}$ & $\begin{array}{c}1390 \pm 190 \\
(\mathrm{P}-\mathrm{I}) 75 \% \\
\mathbf{2 6 2} \pm \mathbf{6 7} \\
(\mathrm{P}-\mathrm{II}) 25 \%\end{array}$ & $\begin{array}{c}1586 \pm 42 \\
(\mathrm{P}-\mathrm{I}) 88 \% \\
288 \pm 84 \\
(\mathrm{P}-\mathrm{II}) 12 \%\end{array}$ & $138 \pm 7$ & $160 \pm 6$ & $168 \pm 29$ \\
\hline A month later & $\begin{array}{c}587 \pm 293 \\
(\mathrm{P}-\mathrm{I}) 70 \% \\
3105 \pm 622 \\
(\mathrm{P}-\mathrm{II}) 30 \%\end{array}$ & $\begin{array}{c}1482 \pm 149 \\
(\mathrm{P}-\mathrm{I}) 60 \% \\
5329 \pm 275 \\
(\mathrm{P}-\mathrm{II}) 40 \%\end{array}$ & $\begin{array}{c}2110 \pm 592 \\
(\mathrm{P}-\mathrm{I}) 89 \% \\
\mathbf{1 6 2} \pm 7 \\
(\mathrm{P}-\mathrm{II}) 11 \%\end{array}$ & $153 \pm 9$ & $179 \pm 5$ & $\begin{array}{c}162 \pm 7 \\
(\mathrm{P}-\mathrm{I}) 70 \% \\
1607 \pm 32 \\
(\mathrm{P}-\mathrm{II}) 30 \%\end{array}$ \\
\hline 3 months later & $\begin{array}{c}2030 \pm 704 \\
(\mathrm{P}-\mathrm{I}) 83 \% \\
\mathbf{5 2 8 8} \pm \mathbf{1 1 8} \\
(\mathrm{P}-\mathrm{II}) 17 \%\end{array}$ & $\begin{array}{c}\mathbf{1 3 5 3 + 2 5 3} \\
(\mathrm{P}-\mathrm{I}) 64 \% \\
\mathbf{5 8 7 6} \pm \mathbf{2 6 1} \\
(\mathrm{P}-\mathrm{II}) 36 \%\end{array}$ & $\begin{array}{c}1965 \pm 408 \\
(\mathrm{P}-\mathrm{I}) 81 \% \\
270 \pm 50 \\
(\mathrm{P}-\mathrm{II}) 19 \%\end{array}$ & $\begin{array}{c}\mathbf{1 5 2} \pm 7 \\
(\mathrm{P}-\mathrm{I}) \mathbf{7 4 \%} \\
\mathbf{9 8 9} \pm \mathbf{1 5 6} \\
(\mathrm{P}-\mathrm{II}) 26 \%\end{array}$ & $\begin{array}{c}191 \pm 74 \\
(\mathrm{P}-\mathrm{I}) 84 \% \\
2984 \pm 198 \\
(\mathrm{P}-\mathrm{II}) 16 \%\end{array}$ & $\begin{array}{c}208 \pm 11 \\
(\mathrm{P}-\mathrm{I}) 85 \% \\
2146 \pm \mathbf{3 8 5} \\
(\mathrm{P}-\mathrm{II}) 15 \%\end{array}$ \\
\hline
\end{tabular}

Table 17. The stability of the 1L6 NPs upon storage.

\begin{tabular}{|c|c|c|c|c|c|c|}
\hline \multirow{4}{*}{ Time } & \multicolumn{6}{|c|}{ Surfactant } \\
\hline & Tween 20 & Tween 80 & Brij 010 & Tween 20 & Tween 80 & Brij 010 \\
\hline & \multicolumn{6}{|c|}{$\mathrm{MPD}(\mathrm{nm}) \pm \mathrm{SD}$} \\
\hline & \multicolumn{3}{|c|}{ At r.t. $\left(23-25^{\circ} \mathrm{C}\right)$} & \multicolumn{3}{|c|}{ Refrigerated $\left(4-5^{\circ} \mathrm{C}\right)$} \\
\hline $\begin{array}{l}\text { Freshly } \\
\text { prepared }\end{array}$ & $132 \pm 7$ & $168 \pm 5$ & $136 \pm 1$ & $132 \pm 7$ & $168 \pm 5$ & $136 \pm 1$ \\
\hline A week later & $154 \pm 5$ & $\begin{array}{c}166 \pm 3 \\
(\mathrm{P}-\mathrm{I}) 71 \% \\
4063 \pm 295 \\
(\mathrm{P}-\mathrm{II}) 29 \%\end{array}$ & $160 \pm 5$ & $154 \pm 1$ & $169 \pm 8$ & $162 \pm 6$ \\
\hline A month later & $\begin{array}{c}156 \pm 3 \\
(\mathrm{P}-\mathrm{I}) 90 \% \\
4782 \pm 192 \\
(\mathrm{P}-\mathrm{II}) 10 \%\end{array}$ & $\begin{array}{c}163 \pm 10 \\
(\mathrm{P}-\mathrm{I}) 70 \% \\
3892 \pm 428 \\
(\mathrm{P}-\mathrm{II}) 30 \%\end{array}$ & $\begin{array}{c}155 \pm 5 \\
(\mathrm{P}-\mathrm{I}) 70 \% \\
4670 \pm 433 \\
(\mathrm{P}-\mathrm{II}) 30 \%\end{array}$ & $157 \pm 3$ & $164 \pm 6$ & $167 \pm 5$ \\
\hline 3 months later & $\begin{array}{c}159 \pm 10 \\
(\mathrm{P}-\mathrm{I}) 70 \% \\
4765 \pm 705 \\
(\mathrm{P}-\mathrm{II}) 30 \%\end{array}$ & $\begin{array}{c}226 \pm 35 \\
(\mathrm{P}-\mathrm{I}) 88 \% \\
5000 \pm 326 \\
(\mathrm{P}-\mathrm{II}) 12 \%\end{array}$ & $\begin{array}{c}160 \pm 8 \\
(\mathrm{P}-\mathrm{I}) 72 \% \\
4580 \pm 425 \\
(\mathrm{P}-\mathrm{II}) 28 \%\end{array}$ & $\begin{array}{c}\mathbf{1 6 0} \pm \mathbf{5} \\
(\mathrm{P}-\mathrm{I}) \mathbf{7 5 \%} \\
\mathbf{4 9 5 9} \pm \mathbf{6 1 7} \\
(\mathrm{P}-\mathrm{II}) 25 \%\end{array}$ & $\begin{array}{c}169 \pm 2 \\
(\mathrm{P}-\mathrm{I}) 80 \% \\
4781 \pm 309 \\
(\mathrm{P}-\mathrm{II}) 20 \%\end{array}$ & $168 \pm 1$ \\
\hline
\end{tabular}

$\mathrm{P}-$ population of the NPs.

Table 18. The stability of the 4F4 NPs upon storage.

\begin{tabular}{|c|c|c|c|c|c|c|}
\hline \multirow{4}{*}{ Time } & \multicolumn{6}{|c|}{ Surfactant } \\
\hline & Tween 20 & Tween 80 & Brij 010 & Tween 20 & Tween 80 & Brij 010 \\
\hline & \multicolumn{6}{|c|}{$\operatorname{MPD}(\mathrm{nm}) \pm \mathrm{SD}$} \\
\hline & \multicolumn{3}{|c|}{ At r.t. $\left(23-25^{\circ} \mathrm{C}\right)$} & \multicolumn{3}{|c|}{ Refrigerated $\left(4-5{ }^{\circ} \mathrm{C}\right)$} \\
\hline $\begin{array}{l}\text { Freshly } \\
\text { prepared }\end{array}$ & $158 \pm 7$ & $157 \pm 7$ & $163 \pm 10$ & $158 \pm 7$ & $157 \pm 7$ & $163 \pm 10$ \\
\hline A week later & $\begin{array}{c}\mathbf{1 3 3} \pm \mathbf{3} \\
(\mathrm{I} \mathrm{p}) 83 \% \\
\mathbf{1 5 7 5} \pm \mathbf{1 5 0} \\
\text { (II p) } 17 \%\end{array}$ & $162 \pm 8$ & $171 \pm 6$ & $161 \pm 4$ & $155 \pm 9$ & $169 \pm 7$ \\
\hline A month later & Full aggregation & Full aggregation & Full aggregation & $166 \pm 6$ & $161 \pm 5$ & $171 \pm 8$ \\
\hline 3 months later & - & - & - & $169 \pm 8$ & $164 \pm 8$ & $173 \pm 9$ \\
\hline
\end{tabular}

P-population of the NPs. 
Table 19. The stability of the 8L6 NPs upon storage.

\begin{tabular}{|c|c|c|c|c|c|c|}
\hline \multirow{4}{*}{ Time } & \multicolumn{6}{|c|}{ Surfactant } \\
\hline & Tween 20 & Tween 80 & Brij 010 & Tween 20 & Tween 80 & Brij 010 \\
\hline & \multicolumn{6}{|c|}{$\operatorname{MPD}(\mathrm{nm}) \pm \mathrm{SD}$} \\
\hline & \multicolumn{3}{|c|}{ At r.t. $\left(23-25^{\circ} \mathrm{C}\right)$} & \multicolumn{3}{|c|}{ Refrigerated $\left(4-5{ }^{\circ} \mathrm{C}\right)$} \\
\hline $\begin{array}{l}\text { Freshly } \\
\text { prepared }\end{array}$ & $\begin{array}{c}159 \pm \mathbf{3} \\
{[0.131 \pm 0.003]}\end{array}$ & $\begin{array}{c}\mathbf{1 6 2} \pm \mathbf{1 5} \\
{[0.107 \pm 0.015]}\end{array}$ & $\begin{array}{c}\mathbf{1 6 6} \pm \mathbf{5} \\
{[0.088 \pm 0.001]}\end{array}$ & $\begin{array}{c}\mathbf{1 5 9} \pm \mathbf{3} \\
{[0.131 \pm 0.003]}\end{array}$ & $\begin{array}{c}\mathbf{1 6 2} \pm \mathbf{1 5} \\
{[107 \pm 0.012]}\end{array}$ & $\begin{array}{c}\mathbf{1 6 6} \pm \mathbf{5} \\
{[0.088 \pm 0.001]}\end{array}$ \\
\hline A week later & $\begin{array}{c}\mathbf{1 7 9} \pm \mathbf{2} \\
{[0.123 \pm 0.007]}\end{array}$ & $\begin{array}{c}\mathbf{1 6 9} \pm \mathbf{1 0} \\
{[0.114 \pm 0.005]}\end{array}$ & $\begin{array}{c}\mathbf{1 8 6} \pm \mathbf{5} \\
{[0.102 \pm 0.011]}\end{array}$ & $\begin{array}{c}\mathbf{1 8 3} \pm \mathbf{8} \\
{[0.135 \pm 0.005]}\end{array}$ & $\begin{array}{c}\mathbf{1 6 7} \pm \mathbf{8} \\
{[0.112 \pm 0.015]}\end{array}$ & $\begin{array}{c}\mathbf{1 8 7} \pm \mathbf{5} \\
{[0.095 \pm 0.004]}\end{array}$ \\
\hline A month later & $\begin{array}{c}\mathbf{1 8 6} \pm \mathbf{7} \\
{[0.129 \pm 0.012]}\end{array}$ & $\begin{array}{c}\mathbf{1 6 5} \pm \mathbf{1 1} \\
{[0.103 \pm 0.009]}\end{array}$ & $\begin{array}{c}\mathbf{1 8 0} \pm \mathbf{3} \\
{[0.094 \pm 0.013]}\end{array}$ & $\begin{array}{c}\mathbf{1 8 9} \pm \mathbf{2} \\
{[0.149 \pm 0.008]}\end{array}$ & $\begin{array}{c}\mathbf{1 8 8} \pm \mathbf{6} \\
{[0.121 \pm 0.005]}\end{array}$ & $\begin{array}{c}\mathbf{1 8 4} \pm \mathbf{9} \\
{[0.109 \pm 0.011]}\end{array}$ \\
\hline 3 months later & $\begin{array}{c}\mathbf{1 9 5} \pm \mathbf{1 0} \\
{[0.145 \pm 0.015]}\end{array}$ & $\begin{array}{c}\mathbf{2 0 0} \pm \mathbf{1 5} \\
{[0.121 \pm 0.004]}\end{array}$ & $\begin{array}{c}\mathbf{1 8 1} \pm \mathbf{3} \\
{[0.113 \pm 0.009]}\end{array}$ & $\begin{array}{c}\mathbf{2 0 0} \pm \mathbf{8} \\
{[0.138 \pm 0.005]}\end{array}$ & $\begin{array}{c}\mathbf{2 0 0} \pm \mathbf{8} \\
{[0.115 \pm 0.010]}\end{array}$ & $\begin{array}{c}\mathbf{1 8 9} \pm \mathbf{2} \\
{[0.118 \pm 0.015]}\end{array}$ \\
\hline
\end{tabular}

\subsection{Morphology of the NPS}

For the morphology study the NPs made of two AABB polymers, 8L6 and 1L6, were selected. The NPs were fabricated at r.t. under the following conditions: the solvent: DMSO; polymer concentration in the organic phase: $6.0 \mathrm{mg} / \mathrm{mL}$; surfactant (Tween 20) concentration in the water phase: $5.0 \mathrm{mg} / \mathrm{mL}$; the $\mathrm{O} / \mathrm{W}$ ratio: 1:10; the organic phase dropping rate: $12 \mathrm{drops} / \mathrm{min}$; and the water phase stirring rate: $700 \mathrm{rpm}$. The suspensions of the NPs were first dialyzed against distilled water for $72 \mathrm{~h}$ to remove the organic solvent and residual surfactant, and then concentrated to $6.0 \mathrm{mg} / \mathrm{mL}$ by evaporating water on a rotary evaporator. The TEM images of the NPs are given in Figure 8.
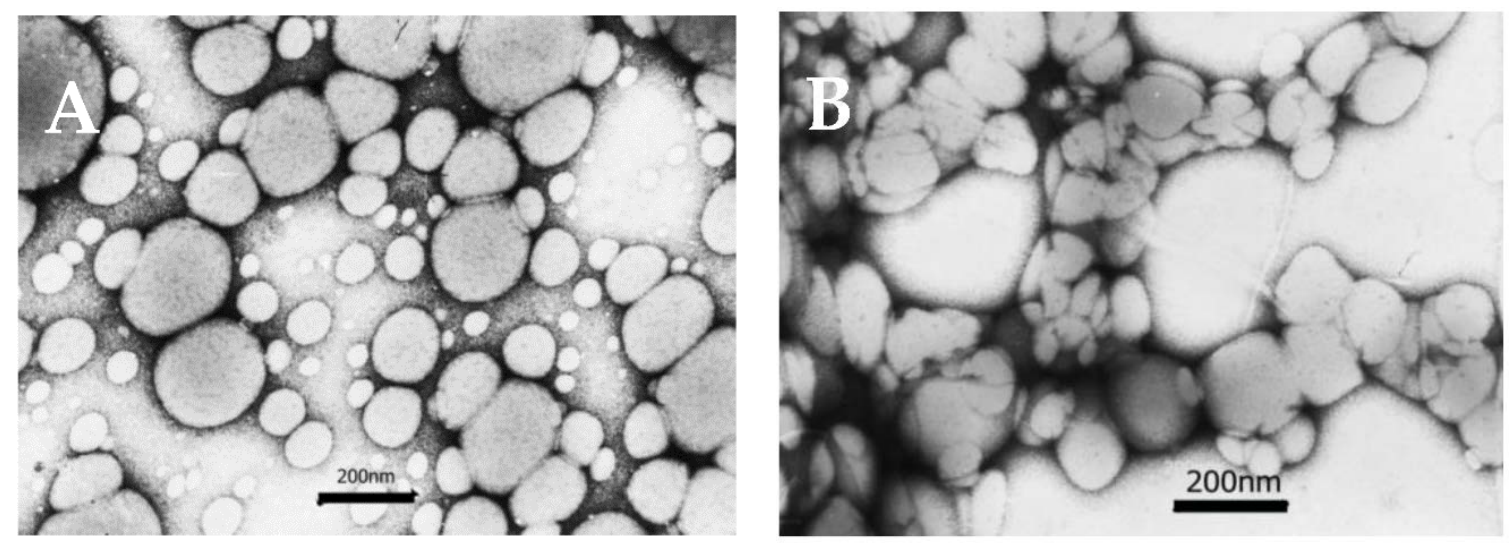

Figure 8. TEM images of 8L6 (A) and 1L6 (B) NPs.

\subsection{Cell Compatibility Study of the NPs}

Prior to the cytotoxicity study of the NPs, the surfactants used during the process of their fabrication were tested for biocompatibility (Figure 9). The three surfactants-Tween 20, Kolliphor P188, and Brij 010 - that gave the best results in terms of the NPs size were selected for this study; the fourth-poly(vinyl alcohol) (Mowiol 4-88)—Which has shown less satisfactory results in terms of the NPs' size, was used as a reference compound since it is known for its low toxicity $[44,45]$. The experiments were performed using four established cell lines-HeLa, A549, Hepa 1-6, and RAW264.7. Based on the results of the cell compatibility study (Figure 9), and taking into account the effectiveness when fabricating the NPs, Tween 20 has been recognized as one of the most promising surfactants for making biocompatible NPs on the basis of the AABB polymers-1F6, 1L6, 4F4, and 8L6. The NPs made from DMSO solution of these polymers in the presence of Tween 20 were subjected to a subsequent cytotoxicity study. The results are given in Figure 10. 

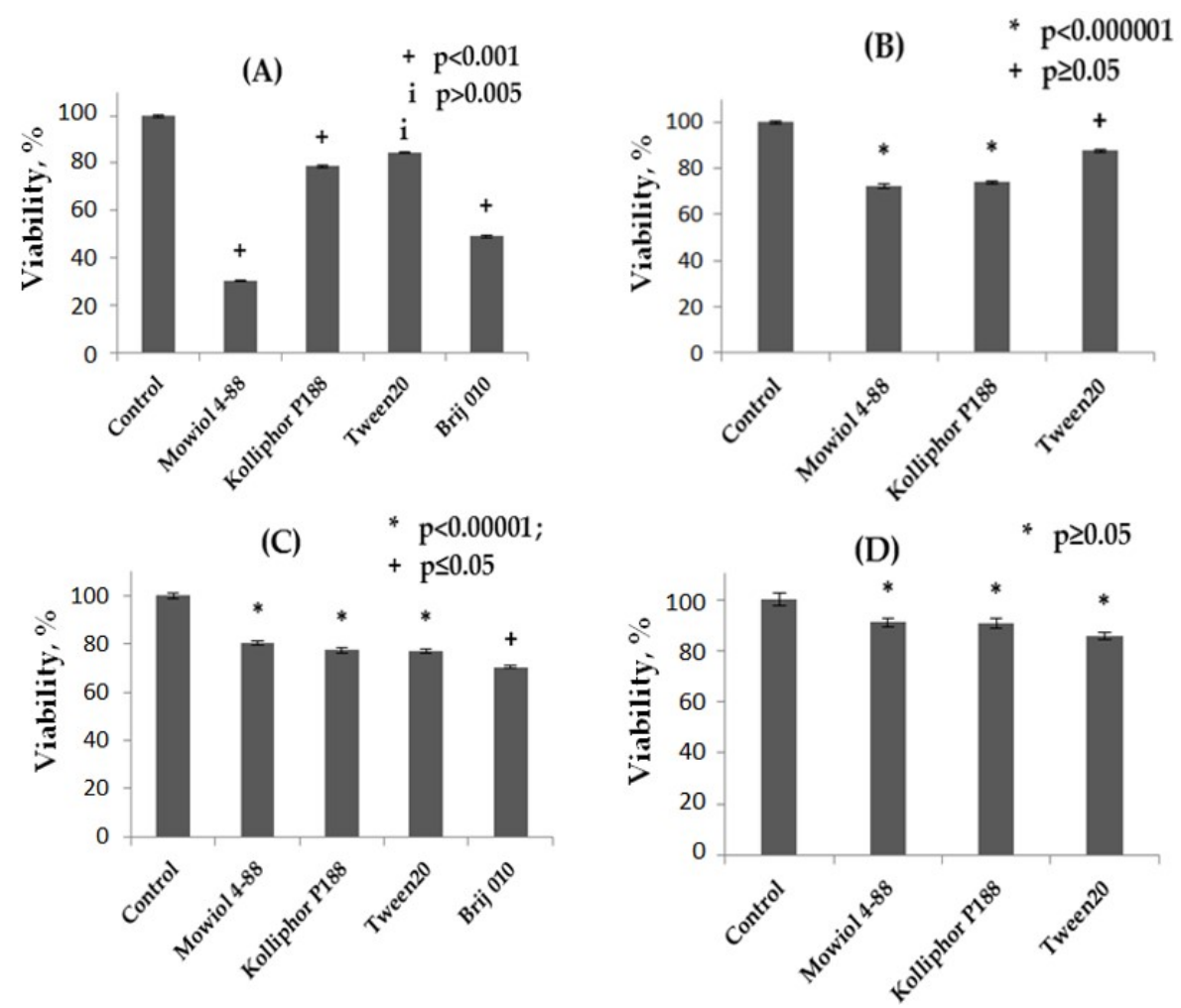

Figure 9. Percentage of viable cells after the $24 \mathrm{~h}$ incubation of four different types of surfactants (2.5 $\mu \mathrm{g} / \mathrm{mL})$ with: (A) HeLa cell line; (B) Hepa 1-6 cell line; (C) A549 cell line; (D) RAW264.7 cell line.
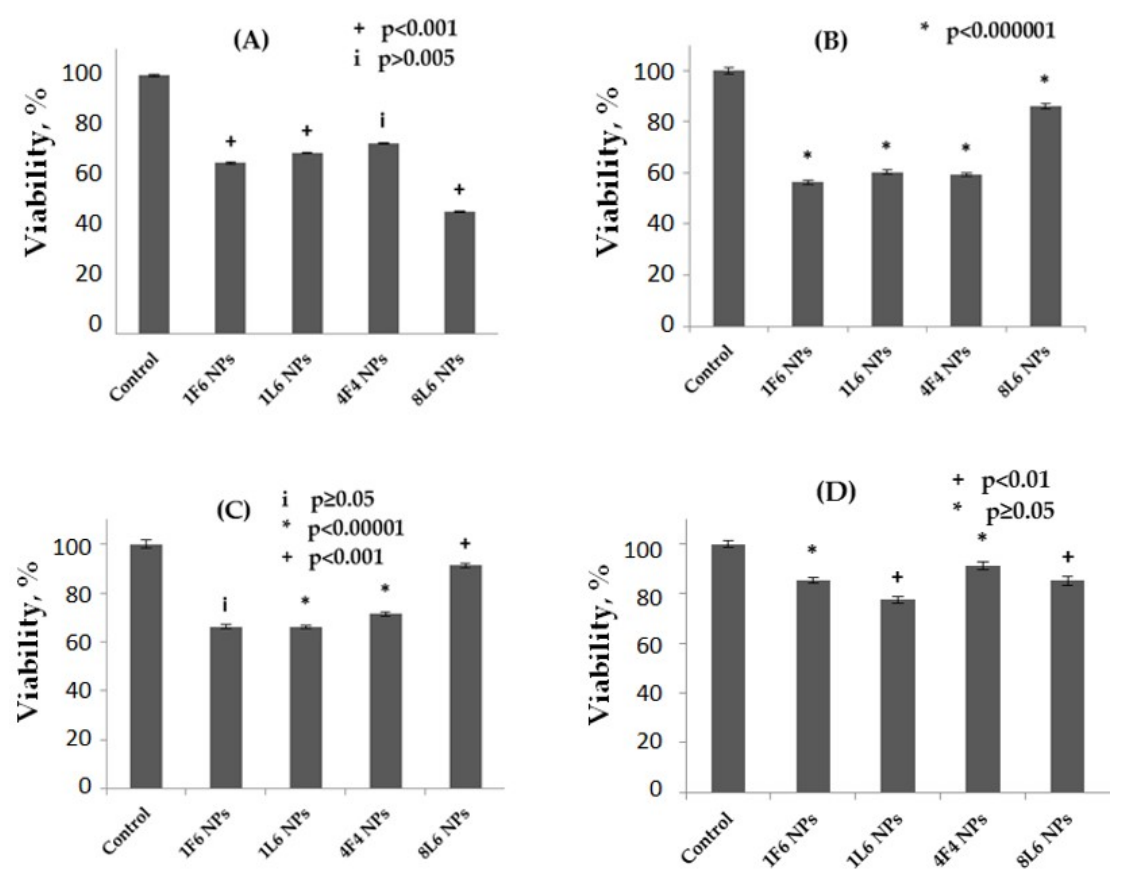

Figure 10. Percentage of viable cells after the $24 \mathrm{~h}$ incubation of four different types of NPs $(5.0 \mu \mathrm{g} / \mathrm{mL})$ with: (A) HeLa cell line; (B) Hepa 1-6 cell line; (C) A549 cell line; (D) RAW264.7 cell line. The NPs were fabricated from DMSO solution in the presence of Tween 20. 


\section{Discussion}

For fabricating the NPs we used a simple procedure consisting of deposition of a biodegradable polymer at the $\mathrm{o} / \mathrm{w}$ interface, followed by solvent displacement from the oily nanodroplets (nanoprecipitation), as reported by Fessi et al. [42] and applied to the poly-(D,L-lactide) polymer. For making the NPs according to the suggested technology we used biodegradable polymers of a new generation, viz. AABB polymers such as two PEUs (1F6 and 1L6) and two PEAs (4F4 and 8L6). Fessi et al. in the reported paper used two surfactants (emulsifiers) - a mixture of phospholipids (Epikuron 170) and poloxamer (Pluronic F68) since maximum stability of suspensions was achieved with a combination of both-nanocapsules precipitated and formed a cake difficult to redisperse when only one emulsifier was used. To search for a system in which the NPs suspension would be stable, in the present systematic study we used eight different surfactants, Tween 20, Tween 40, Tween 80, Triton X-100, Kolliphor P188, Brij 010, Mowiol 4-88, and Mowiol 8-88. In light of the same problem, we examined four organic solvents in the nanoprecipitation procedure. Among the parameters within this systematic study of nanoprecipitation were: a polymer concentration in the organic phase, a surfactant concentration in the aqueous phase, the organic/water phases ratio, the organic phase dropping rate, and the stirring rate of the water phase. The modified method of the NPs fabrication and the method of fabricating the positively charged NPs have been elaborated as well. The new NPs were characterized in terms of the MPD, PDI, ZP, and the stability of the NPs upon storage, as well as by TEM images. The results of this systematic study are discussed in more detail below.

\subsection{Fabrication of the NPs}

4.1.1. The Influence of a Polymer Concentration in the Organic Phase in the Presence of Various Surfactants in the Water Phase

Two phenylalanine-based AABB polymers-The PEU 1F6 and the PEA 4F4-And all eight surfactants were involved in this experiments; DMI was used as an organic solvent. The obtained results, given in Figures 3 and 4, show that increasing a polymer concentration in the organic phase from 0.6 to $6.0 \mathrm{mg} / \mathrm{mL}$ increases MPD-From 42 to $398 \mathrm{~nm}$ for $\mathbf{1 F 6}$, and from 52 to $206 \mathrm{~nm}$ for $4 \mathrm{~F} 4$, depending on the surfactant used. When Tween 20, Tween 40, Tween 80, Brij 010, and Triton X-100 were used as emulsifiers the small NPs with MPD within 89-178 nm were fabricated in the case of all the AABB polymers examined. As to other emulsifiers, Kolliphor P188 resulted in partial aggregation of 1F6, and Mowiol 4-88 and Mowiol 8-88-In partial aggregation of 4F4. In the absence of a surfactant, full aggregation of the NPs was observed (Table 3). Hence, the selection of an appropriate surfactant is very important when fabricating NPs from AABB polymers. The polymer concentration $6.0 \mathrm{mg} / \mathrm{mL}$ was adopted as optimal and used in the subsequent experiments.

\subsubsection{The Influence of a Polymer's Nature}

All four AABB polymers-1F6, 1L6, 4F4, and 8L6-and five emulsifiers-Tween 20, Triton X-100, Brij 010, Mowiol 4-88, and Mowiol 8-88-Were involved in this study; DMI was used as an organic solvent. The results of the experiments, listed in Table 4 in terms of MPD and PDI, show that again Tween 20, Brij 010, Triton X-100 lead to the formation of NPs of small MPD—From 132 to $166 \mathrm{~nm}$. The Mowiols (poly(vinyl alcohol)s), again, resulted in bigger particles and even in a partial aggregation of them. As to PDI, the NPs obtained on the basis of four AABB polymers showed either a mean $(0.04 \leq \mathrm{PDI} \leq 0.16)$ or a wide distribution $(\mathrm{PDI}>0.16)$.

\subsubsection{The Influence of a Surfactant's Concentration in the Water Phase}

Two phenylalanine-based AABB polymers, 1F6 and 4F4, and all four surfactants-Tween 20, Tween 80, Triton X-100, and Brij 010-Were involved in these experiments; DMI was used as an organic solvent. The obtained results, listed in Figure 5 in terms of MPD and PDI, show that surfactant concentration within $2.0-20.0 \mathrm{mg} / \mathrm{mL}$ had no drastic influence on MPD and PDI, though at the 
lowest concentration of $2.0 \mathrm{mg} / \mathrm{mL}$ a partial aggregation of the NPs was observed. In all cases the NPs of reasonable MPD $(\leq 186 \mathrm{~nm})$ with a mean $(0.04 \leq \mathrm{PDI} \leq 0.16)$ or a wide (PDI $>0.16)$ particle distribution were fabricated. Based on the obtained data, $5.0 \mathrm{mg} / \mathrm{mL}$ was adopted as the optimal concentration since further increase of the surfactants' content in the water phase up to $10 \mathrm{or} 20 \mathrm{mg} / \mathrm{mL}$ did not influence the MPD and led only to increased surfactant consumption. Therefore, a surfactant concentration of $5.0 \mathrm{mg} / \mathrm{mL}$ was used in the subsequent experiments.

\subsubsection{The Influence of an Organic Solvent}

Four water-miscible organic solvents-Three highly polar and less volatile, DMI, DMF, and DMSO; and one semi-polar and volatile acetone, which could easily be removed from nanosuspensions by evaporating under reduced pressure [42] -Were used in the present study to form the organic phase containing an AABB polymer. The polar solvents dissolved all four AABB polymers (1F6, 1L6, 4F4 and 8L6), while acetone dissolved the leucine-based polymers, 1L6 and 8L6. The results of the nanoprecipitation experiments for the organic solvents used are listed in Tables 5-8 in terms of MPD and PDI. As one can see from these data, the nature of the organic solvent influenced both NPs size (MPD) and distribution (PDI). DMSO was found as the best solvent from which the NPs of MPD 56-249 $\mathrm{nm}$ were formed depending on the nature of the AABB polymer and the surfactant used. (It has to be taken into consideration that DMSO is a nontoxic organic solvent used in the medical field [46].) The smallest NPs from DMSO were fabricated in the presence of Tween 20, Tween 80, Kolliphor P188, and Brij 010; polyvinyl alcohol (Mowiol 4-88), as above, led to NPs of bigger size in almost all the studied cases. The polydispersity of the NPs fabricated from the DMSO solution varied from mean $(0.04 \leq \mathrm{PDI} \leq 0.16)$ to wide (PDI $>0.16)$. DMI was also found to be a good solvent in terms of the MPD of the fabricated NPs. Among the highly polar organic solvents tested in the nanoprecipitation method, DMF demonstrated the worst characteristics, resulting in NPs of bigger MPD. From the acetone solution the NPs of bigger size were fabricated regardless of the AABB polymer and surfactant used (MPD 172-323 nm); in this case the PDI also varied from mean to wide (mostly) values. However, acetone is a volatile solvent and is very convenient to be removed from the nanosuspensions. This solvent can be recommended for fabricating NPs from the PEA 8L6 using Kolliphor P188, Tween 20, or Brij 010 as the surfactants; the MPDs obtained with these emulsifiers were 172, 192, and $203 \mathrm{~nm}$, respectively, vs. the $229 \mathrm{~nm}$ obtained by Fessi et al. [42] from the acetone solution of poly-(D,L-lactide) using two emulsifiers-A mixture of phospholipids (Epikuron 170) and poloxamer (Pluronic F68).

\subsubsection{The Influence of $\mathrm{O} / \mathrm{W}$ Ratio}

Two phenylalanine-based AABB polymers, $1 \mathbf{F 6}$ and 4F4, and two surfactants, Tween 20 and Brij 010 , were examined in this study; DMI was used as an organic solvent. The $\mathrm{O} / \mathrm{W}$ ratio varied between 1:2, 1:5, 1:10, and 1:20 $(v / v)$. The obtained results, listed in Table 9, show that the optimal O/W ratio is 1:10. Decreasing the volume of the water phase (1:2 and 1:5 ratios) led to the fabrication of bigger NPs-At the lowest 1:2 ratio the formation of micronized particles (the second population of the particles-P-II) and even aggregation of a part of the NPs was observed when Tween 20 was used as a surfactant. A further increase in the $\mathrm{O} / \mathrm{W}$ ratio from 1:10 to 1:20 did not substantially influence either MPD or PDI values, which varied within 138-169 nm and 0.102-0.299, respectively, depending on the AABB polymer and surfactant used. The 1:10 O/W ratio was adopted as optimal and applied to subsequent experiments.

\subsubsection{The Influence of the Organic Phase Dropping Rate to the Water Phase}

Two phenylalanine-based AABB polymers, 1F6 and 4F4, and two surfactants, Triton X-100 and Brij 010, were involved in this study; DMI was used as an organic solvent. Organic phase dropping rates 2, 6, and 12 drops/min were used. The obtained results, given in Figure 6, show that the organic 
phase dropping rate within the experimental error did not influence the MPD. Therefore, the highest dropping rate of 12 drops/min was used in subsequent experiments.

\subsubsection{The Influence of the Stirring Rate of the Water Phase}

Two phenylalanine-based AABB polymers, 1F6 and 4F4, and three surfactants, Tween 20, Triton X-100, and Brij 010, were involved in this study; DMI was used as an organic solvent. The stirring rate of the water phase varied between 250,700 , and $1250 \mathrm{rpm}$. The results of the experiments are given in Figure 7. The stirring rate of $700 \mathrm{rpm}$ was found to be optimal for fabricating NPs. Decreasing the stirring rate to $250 \mathrm{rpm}$ increased the MPD (in some cases it almost doubled it). Increasing the stirring rate up to $1250 \mathrm{rpm}$ did not influence the MPD but in some cases led to a partial aggregation of the NPs, presumably owing to the foaming of the suspension. Therefore, $700 \mathrm{rpm}$ was adopted as an optimal stirring rate and used in subsequent experiments.

\subsection{Modified Method of the NPs Fabrication}

Within the framework of the present study we have elaborated a modified nanoprecipitation method. According to this method a surfactant $(50.0 \mathrm{mg})$ was dissolved in the organic phase $(1.0 \mathrm{~mL})$ along with a AABB polymer $(6.0 \mathrm{mg})$ so that after the dropping of the organic phase into the water phase $(10.0 \mathrm{~mL})$ the surfactant concentration in the water phase would be in line with the established optimal concentration- $5.0 \mathrm{mg} / \mathrm{mL}$.

All four AABB polymers-1F6, 1L6, 4F4, and 8L6 - and five emulsifiers-Tween 20, Triton X-100, Brij 010, Mowiol 4-88, and Mowiol 8-88-Were involved in this study; DMI was used as an organic solvent. The results of the experiments are listed in Tables 10-13. As one can see from these data, the modified method turned out to be effective in the case of the phenylalanine-based polymers 1F6 and 4F4. The obtained NPs are of smaller size compared to the NPs obtained according to the non-modified method; the MPD values are as follows: $108-222 \mathrm{~nm}$ vs. $143-328 \mathrm{~nm}$ for 1 F6, and 79-211 vs. 139-240 nm for 4F4 depending on the surfactant used. In case of the leucine-based polymers 1L6 and 8L6 the NPs made of the modified method are also of smaller size-111-212 nm vs. 132-260 nm for 1L6, and 93-311 vs. 154-181 nm for 8L6 depending on the surfactant used. However, in the case of leucine-based polymers, formation of micronized particles (the second population of the particles-P-II) was observed. For both methods the poly(vinyl alcohol)s-Mowiols turned out to be the worst surfactants, resulting in NPs of bigger size, and, in the case of $4 \mathbf{F 4}$, in partial aggregation of the NPs.

\subsection{ZP of the NPs}

The NPs made of all four AABB polymers-1F6, 1L6, 4F4, and 8L6-In the presence of the most effective surfactants such as Tween 20, Tween 80, and Brij 010 were tested for the ZP. The obtained results, listed in Table 14, show that all the NPs are negatively charged. We suppose that the negative $\mathrm{ZP}$ of the NPs is caused by a partial hydrolysis of the ester links of the AABB polymers that generates free carboxyl groups (carboxylate anions $-\mathrm{COO}^{-}$). The $\mathrm{ZP}$ of the NPs is not too high and varied within $-1.58 \div-12.50 \mathrm{mV}$. Nevertheless, this weak negative charge is sufficient to ensure the stability of NPs upon storage (see below).

\subsection{Fabrication of the Positively Charged NPS}

It is known that a positive charge helps with the NPs' adhesion to the surface and stimulates penetration into the cells $[47,48]$. To impart positive zeta-potential to the NPs we used a blend of neutral AABB polymers, viz. the PEA 8L6 with the arginine-based cationic PEA 8R6 with low cytotoxicity we have originally developed [41]. The PEAs $\mathbf{8 L 6}$ and $\mathbf{8 R 6}$ were blended during the dissolution in DMSO, at that the $\mathbf{8 R 6}$ was added in quantities of $5,10,20,30$, or $50 \mathrm{wt} \%$ of the $\mathbf{8} \mathbf{L} 6$ and the NPs were fabricated using these solutions. The ZPs of the NPs, listed in Table 15, were determined right after the fabrication of the NPs. The obtained results showed that the higher the $8 \mathrm{R} 6$ content in the blend the 
higher the ZP of the NPs, and at $50 \mathrm{wt} \%$ of $8 \mathrm{R} 6$ the $\mathrm{ZP}$ reached $+28.0 \mathrm{mV}$, which is a rather good value for stabilizing the nanosuspension.

\subsection{Stability of the NPs}

Three months stability of the negatively charged NPs made of all four neutral AABB polymers in the presence of three the most effective (within this study) surfactants (Table 14) was studied. The freshly prepared suspensions of the NPs were separated for two parts-One part was stored at r.t. $\left(23-25^{\circ} \mathrm{C}\right.$ ) and another part was refrigerated at $4-5^{\circ} \mathrm{C}$. The results listed in Tables $16-19$ show that the refrigerated suspensions were more stable. The less stable were the NPs made of the PEUs-In case of 1F6 (Table 16) the micronized particles were formed after a weak at r.t.; somewhat higher stability showed the NPs made of $\mathbf{1 L 6}$ (Table 17) —The micronized particles were formed at r.t. after a month storage. After three months virtually all the NPs made of the PEUs, regardless of the storage conditions, formed bigger (micronized) particles, with the exception of the NPs made of 1L6 in the presence of Brij 010 which were stable in a refrigerator-No substantial change of the MPD and no bigger particles' formation was observed (136 nm for freshly prepared, $162 \mathrm{~nm}$ after a weak, $167 \mathrm{~nm}$ after a month, and $168 \mathrm{~nm}$ after three months). The NPs made of the PEAs showed better stability-The NPs made of 4F4 (Table 18), though fully aggregated after a month storage at r.t., but were stable in a refrigerator-No substantial changes of the MPD values of the NPs made in the presence of all three surfactants were observed after three months storage. The best in terms of the NPs stability among the AABB polymers was found the PEA 8L6 (Table 19), which formed highly stable NPs with all three surfactants used-The MPD and the PDI of the NPs were only slightly changed after three months storage at both r.t. and refrigerated.

\subsection{Morphology of the NPs}

Two sample the NPs made of amino acid leucine-based AABB polymers-The PEU 1L6 and PEA 8L6 (Tables 6 and 8, solvent-DMSO, surfactant-Tween 20) were selected for the assessment of morphology of the NPs. According to the DLS measurements the freshly prepared particulates had the following parameters-the 8L6 NPs: MPD $70 \mathrm{~nm}$ and PDI 0.115, the 1L6 NPs: MPD $123 \mathrm{~nm}$ and PDI 0.223, i.e., $\mathbf{8} \mathbf{6} \mathbf{6}$ formed smaller NPs with a mean distribution, and the $\mathbf{1 L 6}$ formed bigger NPs with a wide distribution. Prior to TEM study the nanosuspensions were dialyzed and then concentrated to $6.0 \mathrm{mg} / \mathrm{mL}$. The concentration of the nanosuspensions could affect the parameters of the NPs. To check this issue the concentrated suspensions were re-dilute to the initial concentration $(6.0 \mathrm{mg} / 10 \mathrm{~mL})$ with distilled water. The DLS measurements showed virtually no change of the parameters of the 8L6 NPs after re-dilution: MPD $72 \mathrm{~nm}$ vs. $70 \mathrm{~nm}$ and PDI 0.117 vs. 0.115 that means the $8 \mathrm{~L} 6 \mathrm{NPs}$ were stable upon concentration. In contrast to the $8 \mathrm{L6}$ NPs, the $1 \mathrm{L6}$ NPs were less stable-after re-diluting to $6.0 \mathrm{mg} / 10 \mathrm{~mL}$ the parameters changed as follows: MPD $133 \mathrm{~nm}$ vs. $123 \mathrm{~nm}$ and PDI $0.246 \mathrm{vs}$. 0.223 that can mean that the 1L6 NPs are less stable upon concentration. The TEM images reflect this situation-The 8L6 particulates even after the concentration are close to spherical shape and less aggregated (Figure 8A) whereas the $1 \mathbf{L 6}$ particulates look irregular in shape and more aggregated (Figure 8B). Thus, the morphology study also confirmed that among the studied AABB polymers the PEA 8L6 is the best one for fabricating biodegradable NPs.

\subsection{Cell Compatibility Study of the NPs}

The testing of various surfactants for potential cytotoxicity, using four established cell lines-HeLa, A549, Hepa 1-6, and RAW294.7-Has demonstrated that all three surfactants-Tween 20, Kolliphor P188, and Brij 010-That gave the best results in terms of the NPs' size, in general, have shown almost the same level of cell compatibility as Mowiol 4-88 (poly(vinyl alcohol)), known for its low toxicity $[44,45]$. Among these three surfactants, based on the obtained results (Figure 9), we considered Tween 20 the optimal one. Since this surfactant was also found to be one of the best in terms of particle size (see above), the NPs obtained from the AABB polymers-1F6, 1L6, 4F4, and 8L6-From 
the DMSO solutions in the presence of Tween 20, were tested for cytotoxicity using the mentioned cell lines. The obtained results are given in Figure 10.

During our pilot experiments, the NPs' cytotoxicity has been tested on the A549 cell line, using three different concentrations of all four types of NPs- $-1.0 \mu \mathrm{g} / \mathrm{mL}, 2.5 \mu \mathrm{g} / \mathrm{mL}$, or $5.0 \mu \mathrm{g} / \mathrm{mL}$. No cytotoxicity has been detected for any of the NPs at low concentrations- $1.0 \mu \mathrm{g} / \mathrm{mL}$, or $2.5 \mu \mathrm{g} / \mathrm{mL}$ after $24 \mathrm{~h}$ incubation (data not shown). Aiming to identify the NPs with the highest biocompatibility, we have decided to perform further cytotoxicity testing using the highest concentration of the NPs $-5.0 \mu \mathrm{g} / \mathrm{mL}$. According to the results presented in Figure 10, the 8L6 NPs have revealed the highest level of biocompatibility: the decrease of cell viability for these NPs in the case of three cell lines-A549, Hepa 1-6, and RAW294.7-Was minor and has not exceeded 15\%. The 8L6 NPs at the concentration $5.0 \mu \mathrm{g} / \mathrm{mL}$ appeared to be cytotoxic for only one cell line-HeLa (cell viability (\%): $47.32 \% \pm 0.002 \%$ ). With this cell line the NPs made of other AABB polymers-1F6, 1L6, and 4F4-Were less cytotoxic.

We can speculate that a possible explanation of the NPs' cytotoxicity towards this particular cell line might be a decreased activity of hydrolases in HeLa cells, compared to other cell lines used. Generally, it has been shown recently that HeLa cells have some peculiarities in their metabolism $[49,50]$. A lower proteolytic activity can lead to a slower degradation of the 8L6 NPs inside the cells and, consequently, might cause increased cytotoxicity. Presumably, the intracellular degradation of the NPs made of 1F6, 1L6, and 4F4 proceeded at a higher rate, which diminishes the toxicity of these particulates. At this stage of the research, it was important for us to identify the optimal NPs, including their cell compatibility characteristics. Further experiments focused on these particular NPs will be performed to choose the optimal concentration for potential in vivo applications.

\section{Conclusions}

A systematic study of the NPs fabrication by polymer deposition/solvent displacement (nanoprecipitation) method using four AABB polymers, four organic solvents and eight emulsifiers (surfactants) has been done. The in vitro cell compatibility assessment of the obtained NPs with four established cell lines has been carried out as well. This study revealed that in terms of particles size, stability and biocompatibility the best are: As AABB polymer-Poly(ester amide) composed of L-leucine, 1,6-hexanediol and sebacic acid-8L6, as a solvent (organic phase)—DMSO, and as a surfactant-Tween 20 .

Acknowledgments: The authors thank the Knowledge Fund (Tbilisi, Georgia) and personally Kakha Bendukidze for the financial support of the research. We are grateful to Jordi Puiggali (Universitat Politècnica de Catalunya) for determining MW characteristics of the cationic polymer 8R6.

Author Contributions: Temur Kantaria and Tengiz Kantaria performed the experiments for preparation NPs, contributed analysis tools and participated in the preparation of the manuscript; Sophio Kobauri performed the synthesis of AABB polymers, was engaged in the preparation of NPs and participated in the preparation of the manuscript; Mariam Ksovreli and Tinatin Kachlishvili performed in vitro biocompability and cytotoxicity study of NPs; Nina Kulikova analyzed the data, obtained during the study of biocompability and cytotoxicity, and participated in the preparation of the manuscript; David Tugushi conceived and designed the experiments; Ramaz Katsarava headed the research, analyzed the obtained data and wrote the paper.

Conflicts of Interest: The authors declare no conflict of interest. The founding sponsors had no role in the design of the study; in the collection, analyses, or interpretation of data; in the writing of the manuscript, and in the decision to publish the results.

\section{References}

1. Müller, R.H.; Jacobs, C.; Kayser, O. Nanosuspensions as particulate drug formulations in therapy: Rationale for development and what we can expect for the future. Adv. Drug Deliv. Rev. 2001, 47, 3-19. [CrossRef]

2. Kaur, I.P.; Garg, A.; Singla, A.K.; Aggarwal, D. Vesicular systems in ocular drug delivery: An overview. Int. J. Pharm. 2004, 269, 1-14. [CrossRef] [PubMed]

3. Zimmer, A.; Kreuter, J. Microspheres and nanoparticles used in ocular delivery systems. Adv. Drug Deliv. Rev. 1995, 16, 61-73. [CrossRef] 
4. Sahoo, S.K.; Dilnawaz, F.; Krishnakumar, S. Nanotechnology in ocular drug delivery. Drug Discov. Today 2008, 13, 144-151. [CrossRef] [PubMed]

5. Bochot, A.; Fattal, E.; Boutet, V.; Deverre, J.R.; Jeanny, J.C.; Chacun, H.; Couvreur, P. Intravitreal delivery of oligonucleotides by sterically stabilized liposomes. Investig. Ophthalmol. Vis. Sci. 2002, 43, 253-259.

6. Irache, J.M.; Merodio, M.; Arnedo, A.; Camapanero, M.A.; Mirshahi, M.; Espuelas, S. Albumin nanoparticles for the intravitreal delivery of anticytomegaloviral drugs. Mini Rev. Med. Chem. 2005, 5, 293-305. [CrossRef] [PubMed]

7. Jani, P.D.; Singh, N.; Jenkins, C.; Raghava, S.; Mo, Y.; Amin, S.; Kompella, U.B.; Ambati, B.K. Nanoparticles Sustain Expression of Flt Intraceptors in the Cornea and Inhibit Injury-Induced Corneal Angiogenesis. Investig. Ophthalmol. Vis. Sci. 2007, 48, 2030-2036. [CrossRef] [PubMed]

8. Pignatello, R.; Bucolo, C.; Spedalieri, G.; Maltese, A.; Puglisi, G. Flurbiprofen-loaded acrylate polymer nanosuspensions for ophthalmic application. Biomaterials 2002, 23, 3247-3255. [CrossRef]

9. Kawashima, Y.; Niwa, T.; Handa, T.; Takeuchi, H.; Iwamoto, T.; Itoh, K. Preparation of controlled-release microspheres of ibuprofen with acrylic polymers by a novel quasi-emulsion solvent diffusion method. J. Pharm. Sci. 1989, 78, 68-72. [CrossRef] [PubMed]

10. Bucolo, C.; Maltese, A.; Maugeri, F.; Busà, B.; Puglisi, G.; Pignatello, R. Eudragit RL100 nanoparticle system for the ophthalmic delivery of cloricromene. J. Pharm. Pharmacol. 2004, 56, 841-846. [CrossRef] [PubMed]

11. Sakurai, E.; Ozeki, H.; Kunou, N.; Ogura, Y. Effect of particle size of polymeric nanospheres on intravitreal kinetics. Ophthalm. Res. 2001, 33, 31-36. [CrossRef]

12. Li, V.H.; Wood, R.W.; Kreuter, J.; Harmia, T.; Robinson, J.R. Ocular drug delivery of progesterone using nanoparticles. J. Microencapsul. 1986, 3, 213-218. [CrossRef] [PubMed]

13. Calvo, P.; Vila-Jato, J.L.; Alonso, M.J. Evaluation of cationic polymer-coated nanocapsules as ocular drug carriers. Int. J. Pharm. 1997, 153, 41-50. [CrossRef]

14. De Campos, A.M.; Sánchez, A.; Gref, R.; Calvo, P.; Alonso, M.J. The effect of a PEG versus a chitosan coating on the interaction of drug colloidal carriers with the ocular mucosa. Eur. J. Pharm. Sci. 2003, 20, 73-81. [CrossRef]

15. Giannavola, C.; Bucolo, C.; Maltese, A.; Paolino, D.; Vandelli, M.A.; Puglisi, G.; Lee, V.H.; Fresta, M. Influence of Preparation Conditions on Acyclovir-Loaded Poly-d,l-Lactic Acid Nanospheres and Effect of PEG Coating on Ocular Drug Bioavailability. Pharm. Res. 2003, 20, 584-590. [CrossRef] [PubMed]

16. Vidmar, V.; Pepeljnjak, S.; Jalseniak, J. The in vivo evaluation of poly(lactic acid) microcapsules of pilocarpine hydrochloride. J. Microencapsul. 1985, 2, 289-292. [CrossRef] [PubMed]

17. Knight, D.K.; Gillies, E.R.; Mequanint, K. Strategies in Functional Poly(ester amide) Syntheses to Study Human Coronary Artery Smooth Muscle Cell Interactions. Biomacromolecules. 2011, 12, 2475-2487. [CrossRef] [PubMed]

18. Jacoby, M. Custom-made biomaterials. Chem. Eng. News 2001, 79, 30-35. [CrossRef]

19. Arabuli, N.; Tsitlanadze, G.; Edilashvili, L.; Kharadze, D.; Goguadze, T.; Beridze, V.; Gomurashvili, Z.; Katsarava, R. Heterochain polymers based on natural $\alpha$-amino acids. Synthesis and enzymatic hydrolysis of regular poly(ester amide)s based on bis(L-phenylalanine) $\alpha, \omega$-alkylene diesters and adipic acid. Macromol. Chem. Phys. 1994, 195, 2279-2289. [CrossRef]

20. Kartvelishvili, T.; Tsitlanadze, G.; Edilashvili, L.; Japaridze, N.; Katsarava, R. Amino acid based bioanalogous polymers. Regular poly(ester urethane)s and poly(ester urea)s based on bis(phenylalanine)- $\alpha$, $\omega$-alkylene diesters. Macromol. Chem. Phys. 1997, 198, 1921-1932. [CrossRef]

21. Katsarava, R.; Tugushi, D.; Gomurashvili, Z.D. Poly (ester urea) Polymers and Methods of Use. U.S. Patent 8,765,164, 1 July 2014. Available online: https:/ /www.google.ch/patents/US8765164 (accessed on 1 July 2014).

22. Katsarava, R. Active Polycondensation: From Peptide Chemistry to Amino Acid Based Biodegradable Polymers. Macromol. Symp. 2003, 199, 419-429. [CrossRef]

23. Katsarava, R.; Gomurashvili, Z. Biodegradable Polymers Composed of Naturally Occurring $\alpha$-Amino Acids. Available online: http://onlinelibrary.wiley.com/doi/10.1002/9783527635818.ch5/summary (accessed on 16 December 2016).

24. Defife, K.; Grako, K.; Cruz-Aranda, G.; Price, S.; Chantung, R.; Macpherson, K.; Khoshabeh, R.; Gopalan, S.; Turnell, W.G. Poly(ester amide) Co-polymers Promote Blood and Tissue Compatibility. J. Biomater. Sci. 2009, 20, 1495-1511. [CrossRef] [PubMed] 
25. Sun, H.; Meng, F.M.; Feijen, J.; Dias, A.A.; Hendriks, M.; Zhong, Z. $\alpha$-Amino Acid Containing Degradable Polymers as Functional Biomaterials: Rational Design, Synthetic Pathway, and Biomedical Applications. Biomacromolecules. 2011, 12, 1937-1955. [CrossRef] [PubMed]

26. Ghaffar, A.; Draaisma, G.J.J.; Mihov, G.; Dias, A.A.; Schoenmakers, P.J.; Van der Wal, S. Monitoring the in Vitro Enzyme-Mediated Degradation of Degradable Poly(ester amide) for Controlled Drug Delivery by LC-ToF-MS. Biomacromolecules. 2011, 12, 3243-3251. [CrossRef] [PubMed]

27. Trollsas, M.; Maslanka, B.; Pham, N.; Lin, Q.; Hossainy, S.; Hsu, S.L.; Ngo, M.H. Polyesteramide Coatings for Drug Eluting Stents: Controlling Drug Release by Polymer Engineering. Stud. Mechanobiol. Tissue Eng. Biomater. 2011, 8, 127-143.

28. Díaz, A.; Katsarava, R.; Puiggalí, J. Synthesis, properties and applications of biodegradable polymers derived from diols and dicarboxylic acids: From polyesters to poly(ester amide)s. Int. J. Mol. Sci. 2014, 15, 7064-7123. [CrossRef] [PubMed]

29. Katsarava, R.; Puiggali, J. Leucine Based Polymers: Synthesis and Applications. In Leucine: Biology, Consumption and Benefits; Biochemistry Research Trends; Newman, S.R., Ed.; NOVA Science Publisher: New York, NY, USA, 2015; pp. 17-76.

30. Katsarava, R.; Kulikova, N.; Puiggalí, J. Amino Acid Based Biodegradable Polymers—Promising materials for the applications in regenerative medicine. J. Regener. Med. 2016, 1, 012.

31. Markosishvili, K.; Tsitlanadze, G.; Katsarava, R.; Morris, J.G., Jr.; Sulakvelidze, A. Novel Sustained-Release Matrix Based on Biodegradable Poly(ester amide)s and Impregnated with Bacteriophages and an Antibiotic Shows Promise in Management of Infected Venous Stasis Ulcers and Other Poorly Healing Wounds. Int. J. Dermatol. 2002, 41, 453-458. [CrossRef]

32. Jikia, D.; Chkhaidze, N.; Imedashvili, E.; Mgaloblishvili, I.; Tsitlanadze, G.; Katsarava, R.; Glenn Morris, J., Jr.; Sulakvelidze, A. The Use of a Novel Biodegradable Preparation Capable of the Sustained Release of Bacteriophages and Ciprofloxacin, in the Complex Treatment of Multidrug-Resistant Staphylococcus aureus-Infected Local Radiation Injuries Caused by Exposure to Sr90. Clin. Exp. Dermatol. 2005, 30, 23-26. [CrossRef] [PubMed]

33. Chu, C.C.; Katsarava, R. Elastomeric Functional Biodegradable Copolyester Amides and Copolyester Urethanes. Available online: http://www.google.tl/patents/US7408018 (accessed on 5 August 2008).

34. Lee, S.H.; Szinai, I.; Carpenter, K.; Katsarava, R.; Jokhadze, G.; Chu, C.C.; Huang, Y.; Verbeken, E.; Bramwell, O.; De Scheerder, I.; et al. In Vivo biocompatibility evaluation of stents coated with a new biodegradable elastomeric and functional polymer. Coron. Artery Dis. 2002, 13, 237-241. [CrossRef] [PubMed]

35. Gomurashvili, Z.; Zhang, H.; Da, J.; Turnell, W.G.; Jenkins, T.D.; Hughes, J.; Wu, M.; Lambert, L.; Grako, K.A.; DeFife, K.M.; et al. From drug-eluting stents to biopharmaceuticals: Poly(ester amide) a versatile new bioabsorbable biopolymer. In ACS Symposium Series 977: Polymers for Biomedical Applications; Mahapatro, A., Kulshrestha, A.S., Eds.; Oxford University Press: Oxford, UK, 2008; pp. 10-26.

36. Kropp, M.; Morawa, K.-M.; Mihov, G.; Salz, A.K.; Harmening, N.; Franken, A.; Kemp, A.; Dias, A.A.; Thies, J.; Johnen, S. Biocompatibility of Poly(ester amide) (PEA) Microfibrils in Ocular Tissues. Polymers 2014, 6, 243-260. [CrossRef]

37. Andrés-Guerrero, V.; Zongc, M.; Ramsay, E.; Rojas, B.; Sarkhel, S.; Gallego, B.; de Hoz, R.; Ramírez, A.I.; Salazar, J.J.; Triviño, A. Novel biodegradable polyesteramide microspheres for controlled drug delivery in Ophthalmology. J. Control. Release 2015, 211, 105-117. [CrossRef] [PubMed]

38. Guo, K.; Chu, C.C. Biodegradable and Injectable Paclitaxel-Loaded Poly(ester amide)s Microspheres: Fabrication and Characterization. J. Biomed. Mater. Res. B Appl. Biomater. 2009, 89, 491-500. [CrossRef] [PubMed]

39. Yu, J.; Lin, F.; Lin, P.; Gao, Y.; Becker, M.L. Phenylalanine-Based Poly(ester urea): Synthesis, Characterization, and in vitro Degradation. Macromolecules 2014, 47, 121-129. [CrossRef]

40. Policastro, G.; Lin, F.; Esterle, A.; Harris, F.; Graham, M.; Katsarava, R.; Stakleff, K.S.; Becker, M.L. OGP Functionalized Phenylalanine-based Poly(ester urea) for Enhancing Osteoinductive Potential of human Mesenchymal Stem Cells. In Proceedings of the 249th ACS National Meeting \& Exposition, Denver, CO, USA, 22-26 March 2015.

41. Memanishvili, T.; Zavradashvili, N.; Kupatadze, N.; Tugushi, D.; Gverdtsiteli, M.; Torchilin, V.P.; Wandrey, C.; Baldi, L.; Manoli, S.S.; Katsarava, R. Arginine-based biodegradable ether-ester polymers of low cytotoxicity as potential gene carriers. Biomacromolecules. 2014, 15, 2839-2848. [CrossRef] [PubMed] 
42. Fessi, H.; Puisieux, F.; Devissaguet, J.-P.; Ammoury, N.; Benita, S. Nanocapsule formation by interfacial deposition following solvent displacement. Int. J. Pharm. 1989, 55, R1-R4. [CrossRef]

43. Mosmann, T. Rapid colorimetric assay for cellular growth and survival: Application to proliferation and cytotoxicity assays. J. Immunol. Methods 1983, 65, 55-63. [CrossRef]

44. European Food Safety Authority (EFSA). Opinion of the Scientific Panel on Food Additives, Flavourings, Processing Aids and Materials in Contact with Food on a request from the Commission related to the use of polyvinyl alcohol as a coating agent for food supplements Question number EFSA-Q-2005-017. EFSA J. 2005, 294, 1-15.

45. Baker, M.I.; Walsh, S.P.; Schwartz, Z.; Boyan, B.D. A review of polyvinyl alcohol and its uses in cartilage and orthopedic applications. J. Biomed. Mater. Res. B Appl. Biomater. 2012, 100, 1451-1457. [CrossRef] [PubMed]

46. De la Torre, J.C. Biological actions and medical applications of dimethyl sulfoxide. Ann. N. Y. Acad. Sci. 1983, 411, 1-402.

47. Le Bourlais, C.; Acar, L.; Zia, H.; Sado, P.A.; Needham, T.; Leverge, R. Ophthalmic Drug Delivery Systems-Recent Advances. Prog. Retin. Eye Res. 1998, 17, 33-58. [CrossRef]

48. Mudgil, M.; Gupta, N.; Nagpal, M.; Pawar, P. Nanotechnology: A New Approach for Ocular Drug Delivery System. Int. J. Pharm. Pharm. Sci. 2012, 4, 105-112.

49. Diener, C.; Muñoz-Gonzalez, F.; Encarnación, S.; Resendis-Antonio, O. The space of enzyme regulation in HeLa cells can be inferred from its intracellular metabolome. Sci Rep. 2016, 6, 28415. [CrossRef] [PubMed]

50. Drozd, E.; Krzysztoń-Russjan, J.; Marczewska, J.; Drozd, J.; Bubko, I.; Bielak, M.; Lubelska, K.; Wiktorska, K.; Chilmonczyk, Z.; Anuszewska, E.; et al. Up-regulation of glutathione-related genes, enzyme activities and transport proteins in human cervical cancer cells treated with doxorubicin. Biomed. Pharmacother. 2016, 83, 397-406. [PubMed]

(C) 2016 by the authors; licensee MDPI, Basel, Switzerland. This article is an open access article distributed under the terms and conditions of the Creative Commons Attribution (CC-BY) license (http://creativecommons.org/licenses/by/4.0/). 